$1,\left.19\right|_{\text {LA-5148-MS }}$

4h. 2443

INFORMAL REPORT

A Twenty-Seven Year Study of Selected Los Alamos Plutonium Workers 
This report was prepared as an account of work sponsored by the United States Government. Neither the United States nor the United States Atomic Energy Commission, nor any of their employees, nor any of their contractors, subcontractors, or their employees, makes any warranty, express or im. plied, or assumes any If gai liability or responsibility for the accuracy, completeness or usefulness of any information, apparatus, product or process disclosed, or represents that its use would not infringe privately owned rights.

In the interest of prompt distribution, this LAMS report was not edited by the Technical Information staff.

Printed in the United States of America. Available from

National Technical Information Service

U. S. Department of Commerce

5285 Port Royal Road

Springfield, Virginia 22151

Price: Printed Copy $\$ 3.00$; Microfiche $\$ 0.95$ 


\title{
LA-5148-MS
}

Informal Report

UC-41 \& 48

ISSUED: January 1973

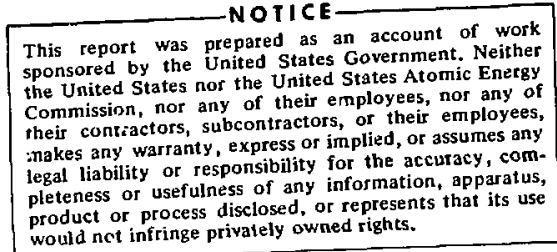

\section{A Twenty-Seven Year Study of Selected Los Alamos Plutonium Workers*}

by

\author{
L. H. Hempelmann ** \\ C. R. Richmond \\ G. L. Voelz
}

Work done by:
E. E. Campbell
W. D. Moss
P. N. Dean
D. F. Peterson
J. W. Healy
C. R. Richmond
L. H. Hempelmann * *
G. L. Voelz
J. N. P. Lawrence
H. O. Whipple
M. F. Milligan

\footnotetext{
"Work supported by the US AEC Division of Biomedical and Environmental Research Contract AT-30-1(4284) to the University of Rochester.

* "Department of Radiology, School of Medicine and Dentistry, University of Rochester, Rochester, New York.
} 
TABLE OF CONTENTS

\section{PREFACE}

I. INTRODUCTION

II. SAFETY PROBLEMS CONCERNED WITH PLUTONIUM PROCESSING

III. PLUTONIUM OPERATIONS CAUSING HEAVY EXPOSURES

A. Recovery Operation

B. Purification Operation

c. Fluorination Operation

D. Reduction Operation

IV. EXPOSURE OF THE SUBJECTS

V. CLINICAL, LABORATORY, AND KADIOACTIVITY OBSERVATIONS

A. Medical Observations 12

B. Plutonium Body Burdens as Detemined by Urine Assay 13

c. Determination of Plutonium in the Body by In Vivo Measurements 15

D. Chromosome Analysis 18

E. Eytology of Exfollated Bronchtal Cells 19

VI. CONCLUDING REMARKS 19

ACKNOWLEDGMENTS

REFERENCES 20

APPENDIX A - DECONTAMINATION PROCEDURES AND RESPIRATORS USED AT LASL IN 1944

APPENDIX B - URINE ASSAY METHOD AND ESTIMATION OF BODY BURDEN 24

APPENDIX $\mathrm{C}$-- MEDICAL FOLLOW-UP OF PATIENT No. 2

APPENDIX D -- RADIATION DETECTION EQUIPMENT FOR IN VIVO MEASUREMENT OF PLUTONIUM 31 
This report of the health of war-time Los Alamos plutonium workers was insp-red by Wright $H$. Langham and is dedicated to his memory. Wright's keen interest in plutonium is known to everyone and, as one of the if not the world's authority on plutonium biochemistry and toxicity, he was the first to be called upon by our government as well as those of other countrles whenever plutontum problems arose. His ultimate concern, of course, was the toxicity of plutonium in man and, in this connection, he organized the UPPU Club composed of the subjects of this study. He kept in cluse touch with ine Club members by periodic circulation of friendly UPPU Newsletters. It was undoubtedly the humor and enthusiasm expressed in these Newsletters that has been responstble for the excellent cooperation of the UPPU Club members in this study.
Wright's intense interest in plutonium continued until his untimely death. In fact, an early draft of this manuscript and a number of now declassifled war-time reports on plutonium experiences were with $h 1 m$ at the time of the fatal plane crash. Although Wright died before he could write his interpretation of the present data, he contributed enormously to the report in the course of discussions of the subfect during the winter of 19711972. Although we are well aware that the study suffers greatly by not having Wright's direct participation, the authora have tried to write a report of which he would have been proud. In an effort to make the report into a personal living story, which 1 t was to Wright, we have Included many of the anecedotes that Wright loved to tell. 
A TWENTY-SEVEN YEAR STULY OF SELECTED LOS ALAMOS PLUTONIUM KORKERS

Compiled and Written by

L. H. Hempelmann, C. R. Richmond, and G. L. Voelz

\title{
ABSTRACT
}

\begin{abstract}
Twenty-five male subjects who worked with plutonfum during Wor1d War II under extraordinarily crude working conditions have been followed medically for a period of 27 years. Within the past year, 21 of these men have been examined at the Los Alamos Scientific Laboratory, and 3 more will be studied in 1973. In addition to physical examinations and laboratory studies (complete blood count, blood chemistry profile, and urinalysis), roentgenograms were taken of the chest, pelvis, knee, and teeth. The chromosomes of lymphocytes cultured from the peripheral blood and cells exfoliated from the pulmonary tract were also studied. Urine specimens assayed for plutonium gave a calculated current body burden (excluding the lungs) ranging from 0.005 to $0.42 \mu \mathrm{Ci}$, and low-energy radiation emit ted by internally deposited transuranic elements in the chest disclosed lung burdens probably of less than approximately $0.01 \mu \mathrm{Ci}$. To date, none of the medical findings in the group can be attributed definitely to internally deposited plutonium. The bronchial cells of several of the subjects showed moderate to marked metaplastic change, but the significance of these changes is not clear. Diseases and physical changes characteristic of a male population entering 1 ts stxth desade were observed. Because of the small body burdens on the order of the maximum permissible level in these men so heavily exposed to plutonium compounds, we conclude that the body has protective mechanisms which are effective in discriminating against these materials following some tjpes of occupational exposures. This is presumably explained by the insolubility of many of 1 ts compounds. Plutonium is more toxtc than radium if deposited in certain body tissues, espectally bone; however, from the practical point of view, plutoniun seems to be less hazardous to handle.
\end{abstract}

\section{INTRODUCTION}

This is the story of how 25 young men were heavily exposed to plutonfum at what is now the Los Alamos Scientific Laboratory (at Los Alamos, New Mexico) in the days of the Manhat:an Project during World War II and of what has happened to them in the subsequent 27 years. All but a few of the subjects of this study were college science majors who were drafted into the Army and assigned to a Special Engineering Detachment of the Manhattan Project. A11 were sent to Los Alamos (Project Y) in 1944 or 1945 and given various technica: jobs in the ChemIstry and Metallurgy Research Dtvision. In these capacities, they were engaged in processing plutonium prior to fabrication and resting of the first atomtc bomb. Almost all of these subjects had body burdens of plutonium eetimated from the urine assay for plutonium used at Los Alamog before 1950 that ranged from 0.1 to $1.2{\mu g^{1}}^{1}(0.006$ to $0.08 \mu C 1)$.
II. SAFETY PROBLEMS CONCERNED WITH PLUTONIUM PROCESSING

The potent:1al danger of exposure to plutontum was recogntzed early in 1944 by 1 ts discoverer, Glenn Seaborg. ${ }^{2}$ He was aware of the similarity of the radioactive properties of plutonium and radium and of the extreme toxicity of the latter element which caused bone cancer in man after deposition of microgram quantities in the body. In an effort to learn more about the biological and metabolic properties of plutonium (and, hopefully, thereby to avert another disaster such as happened in the radium dial painting industiy In the $\left.1920^{\prime} \mathrm{s}\right)$, Seaborg gave about $10 \mathrm{mg}$ of plutonium out of the first half gram produced to Joseph Hamilton of the Crocker Radiation Laboratory in Berkeley, California, for blological experimentation. Thanks to Seaborg's foresightedness, many basic facts related to the blology of plutontum 
were known when the first milligram samples of the material arrived at Los Alamos in the spring of 1944.

However, to be aware of the potential biological hazards of plutonium and to protect against them were two entirely different matters. Safety regulations could be established on the basis of experience in the radium dial paint plants, but protection problems in the two cases differed by many orders of magnitude. (Milligrams of radium in watch plants were subjected to simple mechanical operations, whereas at Los Alamos kilogram quantities of plutonium were involved in complex chemical and metallurgical manipulations.) All work with plutonium was carried out in the wooden Chemistry and Metallurgy Building called "D Building"" (see Fig. 1). Stringent safety regulations put into effect included (a) a complete change of street clothing on entrance to the contarinated areas with two changes per day of freshly laundered coveralls, canvas bootees, and surgical caps (all persons showered on leaving the building); (b) use of

\footnotetext{
* It is a matter of interest to modem day plutoniım workers that the air entering the $\mathrm{D}$ Building was cleansed of dust by electrostatic precipitation methods. However, air leaving the building was unfiltered for the most part, since few, if any, of the exhausts even from plutonium-containing hoods had filters.
}

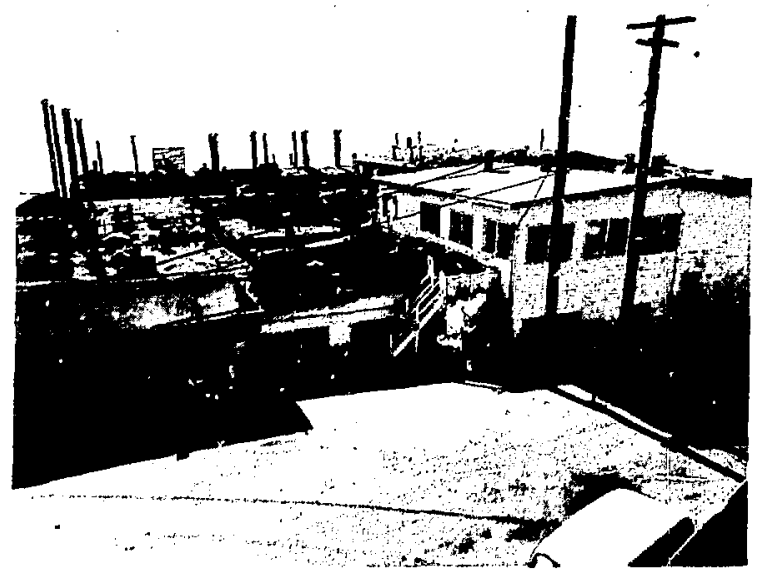

Fig. 1. The original wooden D Buflding which housed the chemists and metallurgists in CMR Division. Note that the chemical hoods of the laboratories on the first floor were vented individually, usually without filtration. surgical rubber gloves and respirators (Wilson 750) during all chenical procedures involving plutonium; and (c) whenever possible, use of closed system; (at first, homemade dryboxes with rubberized canvas sleeves at tached to surgical gloves). Sometimes it was impractical to use a closed system, and chemical hoods had to be used (not made of stainless steel in the early days). All workers were fully apprised of the hazards of plutonium (as they were then known) and were required to sign a statement saying they would abide by the safecy rules. With rare exceptions, the workers cooperated to the best of their ability, although during the tension and feverish activity of developing the first atomic weapons it was difficult to avoid some shortcuts in the observation and enforcement of safety rules.

When milligram quantities of plutonium first became available to Los Alamos chemists and metallurgists, efforts to live with what was considered to be safe contamination levels were hampered by the fact that portable alpha counters and continuous air samplers had not yet been developed. However, because of the .rrgency of the times, work with pluconiun had to proceed, and improvised methods of monitoring and decnntamination were unbelievably frimltive by today's standards (see Appendix A). Because stationary counters were the only means of detecting alpha particles from plutonium, ${ }^{* \star}$ It was necessary to make "swipes" with lightly olled filter paper of the: laboratory surfaces considered most likely to be contaminated and to bring these paper strips to the alpha proportional counter for counting. This was done systematically on a daily basis (or after an accident) in each laboratory containing plutonium (6 swipes per laboratory). Any "swiped" area (approximately $6 \times 6$ in.) having an activity of more than 500 counts per minute required

\footnotetext{
** There was a semi-portable counter called Pluto first available in March 1944, but it was very bulky and its limit of sensitivity was 5000 counts per minute. A more sensitive yet still cumbersome counter called Supersnoop came into use in March 1945, but it was not until the instrument called i-oppy became available In June 1945 that the monitoring situation really was under control. Hand counters were not avallable unt1l October 1944 , when the flrst experimental models capable of detecting 200 counts per minute vere installed in the locker rooms.
} 
decontanination. $* * *$ It is difficult to believe but, because of the bulkiness and inconvenience of the early so-called portable counters, the swipe technique of montoring was continued in some laboratories until June 1945. Similarly, in the absence of air samplers for radioactive dusts (the first became available in the fall of 1944), both nostrils of each plutonium worker were "swiped" routirely with rolled moistened strips of filter paper at the end of the working day or if accidental pulmonary exposure was suspected. These samples were also counted in a stationary alpha particle counter. If the nose swipe exceeded 50 counts per minute, the subject was questioned carefully about possible accidental inhalation or breakage of safety regulations (e.g., hand contamination of the nostrils).

In April 1945, kilogram quantities of plutonium from the newly operating Hanford piles began to arrive at Los Alamos for processing and fabrication into the first atomic bombs. Fortunately, by this time portable alpha counters (Fig. 2) and continuously operating air samplers were available to help with monitoring for contamination of certain laboratories. Operating equipment, including air lines in some laboratories and speclally made positive-pressure masks, also had been improved. Al though rost procedures were carried out in dryboxes, some work had to be done in open hoods (Fig. 3). This was particularly true in the case of the Recovery Group, the act 1 vities of which were so diverse and unstandardized that closed svsteins were totally inoperable. ${ }^{3}$ Also by March 1945, a

The swipe technique measured only alpha particleenitting materials not fixed to the surface. 011 on the filter paper used for surface swipes probably decreased somewhat the measurable alpha activity. The molstened paper strips used for nose counts were dried before counting; consequently, the measured activity was probably more accurate than that of the ofled swipes. The geometry of the stationary proportional counter was relatively good, approaching 50 percent. In contrast to poorly fixed radioactivity measured by the swipe technique, portable counters developed later measured fixed as well as unflxed radioactive contamination with a rather poor geometry (10 to 15 percent).

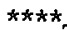

The nose counts and a1r counts (at first one sampler in the most hazardous laboratory) were by no means accurate measures of exposure of personnel. At best, they were merely crude indications that permissible contamination levels had been exceeded or that safety regulations might have been violated.

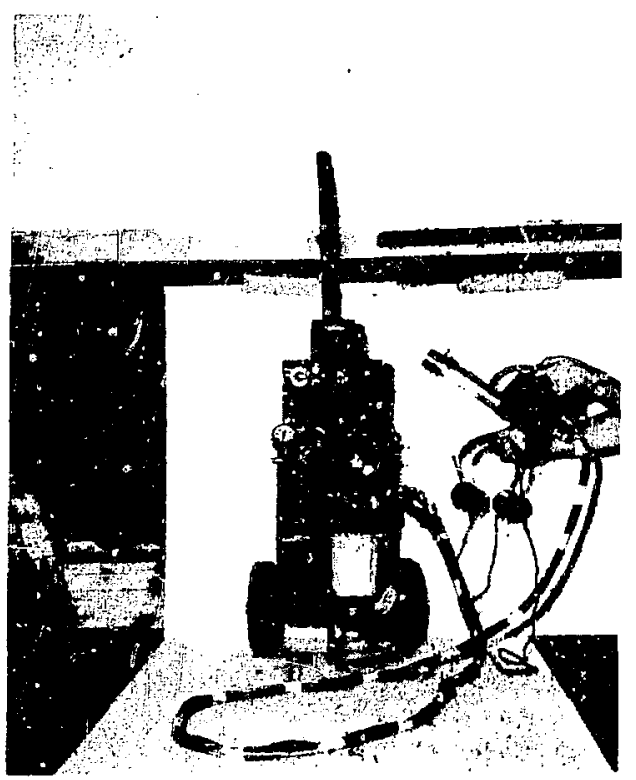

Fig. 2. A semi-portable alpha counter called "Supersnoop" used in early 1945.

urine assay method for plutonium ${ }^{4}$ had been developed; this allowed crude estimates of the body burdens of plutonium to be made (not including insoluble compounds in the $1 \mathrm{ung}$ ). However, even with improvements

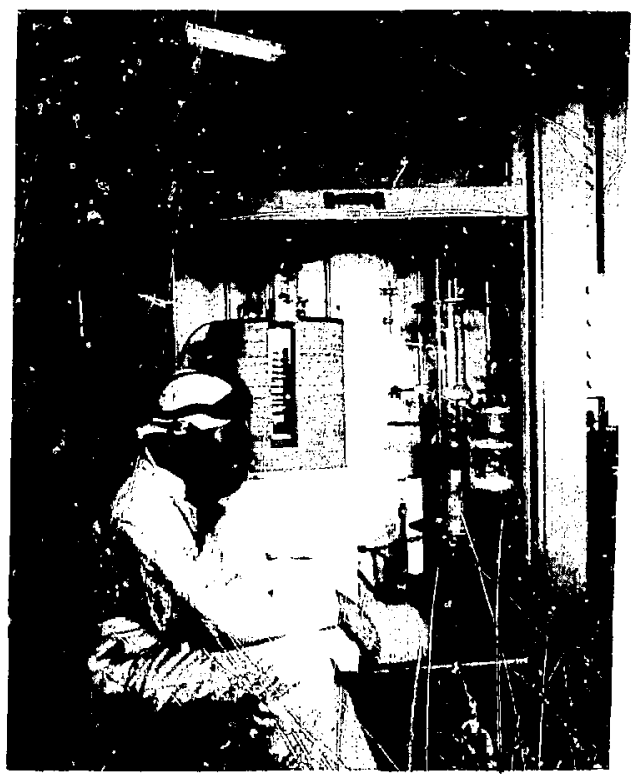

F1g. 3. One of the steps in the purification operation performed in an open chemical hood. The operator is wearing the standard prom rective clothing and respirator (Wilson 750). 
in monitoring techniques, work1ng conditions were deplorable by present-day standards. Fortunately, after initial bomb processing was completed in August 1946, all work with plutonium was sharply curtailed until the new and greatly improved facilitfes at DP Stte in Los Alamos were opened in September 1946.

To illustrate the degree of contamination of laboratories In D Buflding in 1944 and 1945, we will present a few almost random experiences taken from various reports issued at the time. Table I shows the maximum and minimum "swipe" counts in all laboratories in D Butlding in March 1944 [500 counts per minute correspond to $0.007 \mathrm{Hg}$ or $0.0004 \mu \mathrm{CA}$ cf plutonium isotope mixture of that time; note the $2,500,000$ count per minute (or $35 \mu \mathrm{g}$ ) swipe in $\mathrm{D}-117$ (used by the Recovery Group ${ }^{\star \star \star \star \star}$ )]. Figure 4 shows

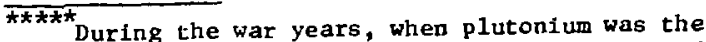
primary concern of the radiochemists, the unit of measure of plutonium was usually considered to be its weight (1.e., micrograms, grams, etc.). In the $1950^{\prime} \mathrm{s}$, presumably because of the influence of the health physicists (and because chemists became more tnvolved with physics), radioactivity (1.e., microcuries, etc.) became the unit of measure. Both units are given throughout this paper.

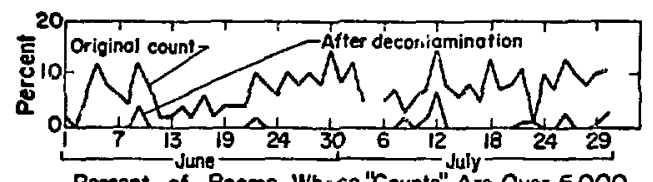

Percent of Rooms Whose "Counts" Are Over 5,000

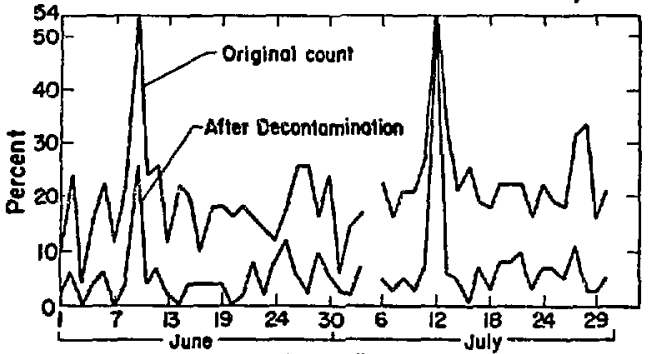

Percent of Rooms Whose "Counts" Are Between 500 and 5,000

Fig. 4. Chart showing the percent of laboratories in D Building in June and July 1945 with "hot" spots requiring decontamination. The lower line indicates the counts after decontamination. Note that about 50 percent of the laboratories had contamination in excess of 500 counts per minute on two occasions.

TABLE I

MAXIMUM AND MINTMUM SWIPE COUNTS IN D BULLDING (MARCH 1944)

\begin{tabular}{|c|c|c|c|c|c|c|c|c|c|c|}
\hline $\begin{array}{l}\text { Room No. } \\
\text { First } \\
\text { Maximum } \\
\text { Minimum } \\
\text { Last }\end{array}$ & $\begin{array}{r}101 \\
16 \\
274 \\
0 \\
18\end{array}$ & $\begin{array}{r}102 \\
158 \\
3,319 \\
32 \\
642\end{array}$ & $\begin{array}{r}103 \\
1.10 \\
739 \\
24 \\
122\end{array}$ & $\begin{array}{r}104 \\
399 \\
14,560 \\
12 \\
150\end{array}$ & $\begin{array}{r}108 \\
338 \\
4,652 \\
60 \\
826\end{array}$ & $\begin{array}{r}109 \\
177 \\
4,078 \\
50 \\
3,547\end{array}$ & $\begin{array}{r}110 \\
321 \\
15,176 \\
59 \\
59\end{array}$ & $\begin{array}{r}112 \\
807 \\
17,450 \\
27 \\
51\end{array}$ & $\begin{array}{r}113 \\
308 \\
561 \\
17 \\
57\end{array}$ & $\begin{array}{r}114 \\
10 \\
172 \\
4 \\
31\end{array}$ \\
\hline $\begin{array}{l}\text { Room No. } \\
\text { First } \\
\text { Maximum } \\
\text { Minimum } \\
\text { Last }\end{array}$ & $\begin{array}{r}115 \\
33 \\
70 \\
0 \\
21\end{array}$ & $\begin{array}{r}116 \\
9 \\
58 \\
9 \\
37\end{array}$ & $\begin{array}{r}117 \\
8 \\
2,500,000 \\
0 \\
1,198\end{array}$ & $\begin{array}{r}118 \\
244 \\
6,000 \\
1 \\
2,368\end{array}$ & $\begin{array}{r}119 \\
10 \\
1,387 \\
10 \\
48\end{array}$ & $\begin{array}{r}120 \\
3 \\
816 \\
1 \\
22\end{array}$ & $\begin{array}{r}121 \\
0 \\
81 \\
0 \\
42\end{array}$ & $\begin{array}{r}122 \\
12 \\
128 \\
0 \\
24\end{array}$ & $\begin{array}{r}123 \\
90 \\
130 \\
12 \\
64\end{array}$ & $\begin{array}{r}124 \\
7 \\
176 \\
5 \\
46\end{array}$ \\
\hline $\begin{array}{l}\text { Room No. } \\
\text { First } \\
\text { Maximum } \\
\text { Minimum } \\
\text { Last }\end{array}$ & $\begin{array}{r}125 \\
40 \\
4,592 \\
16 \\
506\end{array}$ & $\begin{array}{r}126 \\
73 \\
17,832 \\
19 \\
28\end{array}$ & $\begin{array}{r}127 \\
44 \\
363 \\
2 \\
22\end{array}$ & $\begin{array}{r}128 \\
52 \\
94 \\
0 \\
46\end{array}$ & $\begin{array}{r}129 \\
83 \\
83 \\
0 \\
6\end{array}$ & $\begin{array}{r}130 \\
42 \\
3,173 \\
10 \\
71\end{array}$ & $\begin{array}{r}132 \\
6 \\
5,796 \\
1 \\
85\end{array}$ & $\begin{array}{r}133 \\
41 \\
610 \\
3 \\
13\end{array}$ & $\begin{array}{r}134 \\
58 \\
68 \\
0 \\
25\end{array}$ & $\begin{array}{r}136 \\
6 \\
3,712 \\
0 \\
91\end{array}$ \\
\hline $\begin{array}{l}\text { Room No, } \\
\text { First } \\
\text { Maximum } \\
\text { Mintmum } \\
\text { Last }\end{array}$ & $\begin{array}{r}137 \\
93 \\
2,928 \\
0 \\
833\end{array}$ & $\begin{array}{r}138 \\
7 \\
448 \\
6 \\
33\end{array}$ & $\begin{array}{r}139 \\
23 \\
23 \\
7 \\
12\end{array}$ & $\begin{array}{r}140 \\
81 \\
81 \\
12 \\
12\end{array}$ & $\begin{array}{r}141 \\
0 \\
15 \\
0 \\
2\end{array}$ & $\begin{array}{r}142 \\
51 \\
51 \\
20 \\
20\end{array}$ & $\begin{array}{r}143 \\
8 \\
15 \\
8 \\
8\end{array}$ & $\begin{array}{r}144 \\
0 \\
0 \\
0 \\
30\end{array}$ & $\begin{array}{r}145 \\
0 \\
114 \\
0 \\
126\end{array}$ & $\begin{array}{r}146 \\
338 \\
338 \\
5 \\
16\end{array}$ \\
\hline $\begin{array}{l}\text { Room No. } \\
\text { F1rst } \\
\text { Maximum } \\
\text { MIntmum } \\
\text { Last }\end{array}$ & $\begin{array}{r}148 \\
30 \\
30 \\
20 \\
20\end{array}$ & $\begin{array}{r}151 \\
30 \\
79 \\
18 \\
36\end{array}$ & $\begin{array}{r}152 \\
0 \\
104 \\
0 \\
42\end{array}$ & $\begin{array}{r}201 \\
23 \\
23 \\
23 \\
23\end{array}$ & $\begin{array}{r}202 \\
9 \\
9 \\
9 \\
9\end{array}$ & $\begin{array}{r}203 \\
23 \\
23 \\
23 \\
23\end{array}$ & $\begin{array}{r}204 \\
0 \\
0 \\
0 \\
0\end{array}$ & $\begin{array}{r}205 \\
21 \\
21 \\
21 \\
21\end{array}$ & $\begin{array}{r}207 \\
45 \\
45 \\
45 \\
45\end{array}$ & $\begin{array}{r}209 \\
73 \\
73 \\
73 \\
73\end{array}$ \\
\hline
\end{tabular}


the percent of laboratories in June and July 1944 in which radioactivity levels (as measured by swipes) were above 5000 counts per minute or were between 500 and 5000 counts per minute. Table II shows the high nose counts (over 50 counts per minute) of three chemists in the Recovery Group (other nose counts of these men not included were consistently positive but below 50 counts per minute). In April 1945, 1243 "hot" (over 500 counts per minute) spots, mostly detected by portable counters, were decontaminated. In June, July, and August 1945, the number of decontamination procedures carried out were 1980,3489 (of which 760 exceeded 30,000 counts per minute), and 5347, respectively. Lest the reader think that the operations were lax or careless, he should be advised that a J.arge, welltrafined monttoring staff of approximately 41 persons worked overtime to maintain the safety standards with the crude methods available. Pressures to build the bomb were so great that work had to proceed using the best, although admittedly unsatisfactory, safety measures of the times.

\section{PLUTONIUM OPERATIONS CAUSING HEAVY EXPOSURES}

Twenty-three of the 25 living exposed sub-
jects ${ }^{* \star * *}$ worked in four operating groups: Plutonium Purification (wet chemistry), Plutonium Fluorination (dry chemistry), Plutonium Reduction (to metal), and Plutonium Recovery. Because the last operation was by far the most hazardous, it w111 be described first. Monthly reports of the Chemistry and Metallurgy Research and Health Divistons submitted in 1944 and 1945 (many still classified), as we1l as references 3 and 5 , are the source of much of the material in this section. Extensive interviews with the subjects and their supervisors, as well as with the health monitors, provided supplementary information.

\section{A. Recovery Operation}

Fourteen of the 25 subjects with measurable body burdens of plutonium worked in the recovery operation between March 1944 and September 1946.

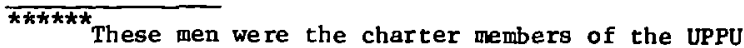
Club formed by Wright Langham when this study began in the early $1950^{\prime} \mathrm{s}$. In essence, the acronym represents the phrase "you excrete plutonium." The name was criginally IPPU, but Langham dectded this was too personal.
}

This group was charged with the following responsibilities: (a) recovery of the then priceless plutonium which had been efther left behind in any of the experimental or operational procedures or spilled accidentally or lost as contamination, and (b) converting the recovered plutonium to the +4 valence state suitable for fluorination and subsequent reduction to plutonium metal.

In 1944, the Recovery Group dealt first with mlligram and later with gram amounts of plutonium; however, in March 1945, as a resulit of increased quantities being processed by the Chemistry and Metallurgy Division, the Laboratory began to handle kilogram quantities of plutonium. During peak work perlods, the staff worked 12-hour shifts 7 days a week. Fortunately, by this time new laboratory facilities were in use in an annex of the old $D$ Building. A suite of three laboratories (maintained under reduced pressure) had replaced the ungle laboratory $\mathrm{D}-117$. These laboratories had open stainless steel hoods instead of the ordinary chemtcal hoods previousiy used in D-117. Although two of these laboratories were equipped with air lines, the commercially avallable positive-pressure masks were not entirely satisfactory in protecting personnel from airborne contamination. Not until July 1945, when a specially wade mask (called the Kenmedy-Hinch mask, ${ }^{\star \star \star \star \star \star \star}$ after 1 ts designers) was developed, was there comparatively good protection against airborne radioactivity.

The types of plutonium-containing materials submitted to the Recovery Group for processing included analytical residues; washings (supernatant solutions) frow various steps in the wet purification of plutonium; metalitc scraps, shavings, and trimmings; crucibles composed of various materials used in the reduction of $\mathrm{PuF}_{4}$; absorbent materials used to wipe up accidental spills and other contaminated materials; graphite tubes used in oxygen analysis; and drybox and chemtcal hood sweepings.

After considerable experimentation, the following basic procedure was adapted for recovery operations (see Fig. 5) $\overline{\hbar \star \hbar \hbar \hbar \hbar \hbar}$ The late Joseph $W$. Kennedy was the leader of CMR Division.

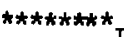

It should be mentioned that not all of the recovered plutonium went through the entire procedure. Depending upon the chemical nature and purity of the plutonium befng recovered, various steps of the total procedure were omitted. 
TABLE II

EXAMPLES OF SUBJECTS WITH NOSE COUNTS ABOVE 50 COUNTS PER MINUTE

Date Nose Counts

Subject No.

\begin{tabular}{|c|c|}
\hline $\begin{array}{c}4-17-44^{b} \\
28 \\
7-19-44\end{array}$ & $\begin{array}{l}175 \\
199 \\
207\end{array}$ \\
\hline $10-12-44$ & -144 \\
\hline $11-7-44$ & 188 \\
\hline $12-29-44$ & 207 \\
\hline $\begin{array}{l}4-20-45 \\
5-8-45\end{array}$ & $\begin{array}{l}717-408 \\
174-113\end{array}$ \\
\hline 15 & $73-27$ \\
\hline 16 & $196-172$ \\
\hline 18 & $421-41$ \\
\hline 19 & $127-107$ \\
\hline 21 & $138-129$ \\
\hline 22 & $62-22$ \\
\hline 29 & $101-67$ \\
\hline 31 & $250-87$ \\
\hline $6-4-45$ & $930-82$ \\
\hline 5 & $272-174$ \\
\hline 6 & $163-43$ \\
\hline 7 & $267-131$ \\
\hline 9 & $177-118$ \\
\hline 14 & $170-165$ \\
\hline 15 & $504-416$ \\
\hline 16 & $246-514$ \\
\hline 18 & $720-501$ \\
\hline 19 & $2559-3111$ \\
\hline 20 & $199-150$ \\
\hline 23 & $320-200$ \\
\hline 25 & $126-78$ \\
\hline 26 & $608-94$ \\
\hline 27 & $68-50$ \\
\hline $7-2-45$ & $217-182$ \\
\hline 4 & $336-316$ \\
\hline 5 & $\begin{array}{l}394-182 \\
324-182^{c}\end{array}$ \\
\hline 6 & $218-122$ \\
\hline 7 & $486-152$ \\
\hline 9 & $128-108$ \\
\hline 10 & $92-56$ \\
\hline 11 & $\begin{array}{r}520-394 \\
1096-329^{c}\end{array}$ \\
\hline 12 & $64-80$ \\
\hline 13 & $100-80$ \\
\hline 14 & $100-60$ \\
\hline & $148-130^{\circ}$ \\
\hline 16 & $96-76$ \\
\hline 17 & $100-96$ \\
\hline 23 & $70-66$ \\
\hline 25 & $64-52$ \\
\hline $13-17-45$ & $696-90$ \\
\hline 20 & $144-48$ \\
\hline 23 & $88-26$ \\
\hline 24 & $76-60$ \\
\hline
\end{tabular}

Date Nose Counts

Subject No. 8$$
\text { 6- }
$$

4

$5 \quad 231-2.13$

6 20-60

7 291-201

9 286-89

I1 1181-323

12 454-385

13 1107-1292

$14 \quad 509-229$

$15 \quad 623-560$

16 1208-680

$18 \quad 146-92$

19 928-615

$20 \quad 1506-1009$

22 1898-1100

23

$7-2-45$

90-23

400-274

164-170

$236-97^{\mathrm{c}}$

324-126

$198-118^{\mathrm{C}}$

$338-278$

268-72

1016-694

484-304

$250-247$

198-166

$356-328$

364-328

462-410

$752-545$

$179-183^{\mathrm{C}}$

941-243

898-816

322-160

166-154

768-652

124-56

202-100

300-136

106-78

165-107

136-72

17

5- 8-46

52-825

6-17-46 168-401

Date Nose Counts Subject No. 9

$\begin{array}{cc}6-28-45 & 372-146 \\ 29 & 562-98 \\ 30 & 698-664 \\ 7-2-45 & 70-64 \\ 3 & 208-140 \\ 6 & 112-80 \\ 9 & 1164-608 \\ & 608-626^{c} \\ 10 & 57-50 \\ 11 & 879-706 \\ 23 & 838-842 \\ & 1296-306^{c} \\ 25 & 164-408 \\ 30 & 3040-464 \\ 31 & 2086-482 \\ 8-2-45 & 8976-5180 \\ 3 & 660-204 \\ 4 & 674-530 \\ 6 & 3922-1752\end{array}$

${ }^{a}$ Counte per minute of activity swiped frcin each nostril.

$b_{\text {Only one nostril swabbed. }}$

c Accidental expoeure suspected. 
FLOW SHEET FOR RECOVERY B PURIFCATION OF PLUTON:UM

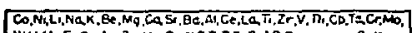

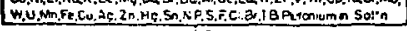

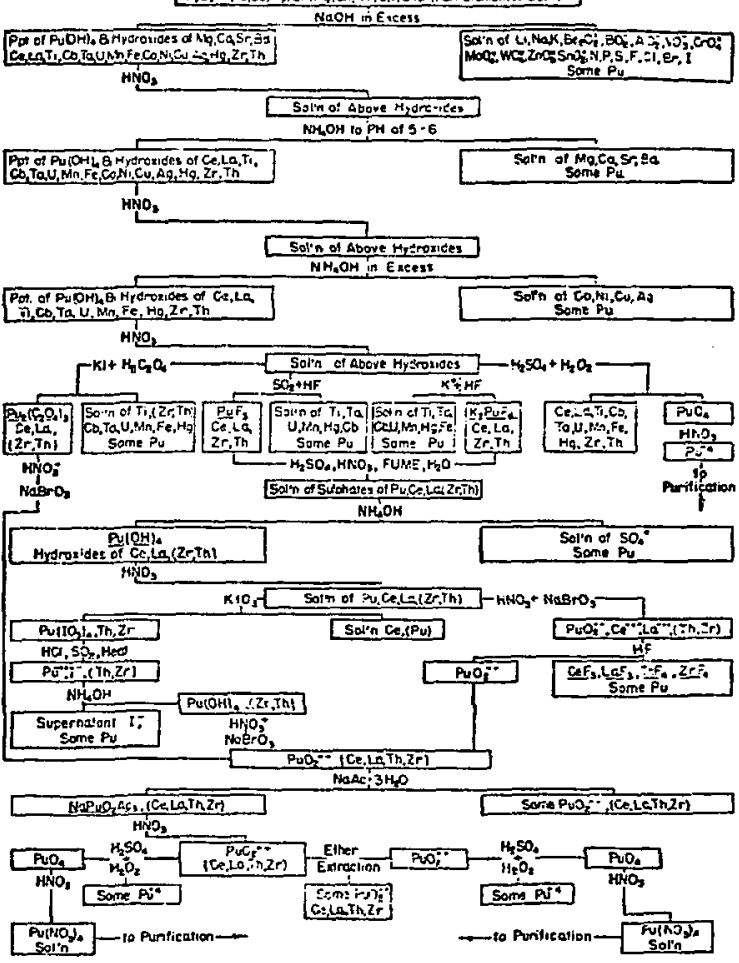

F1g. 5. Flow sheet for the recovery operation. 3 This gives the general outline of the procedures used, but each individual recove: $y$ operation requiled spectal conditions.

plutonlum were dissolved directly in HCl; insoluble. salts (oxides or carbides) also were dissolved in actd after persulfate or carbonate fusion; (b) plutonium was preclpitated with $\mathrm{NaOH}$ or $\mathrm{NH}_{4} \mathrm{OH}$; (c) plutonium hydroxide was dissolved in $\mathrm{HNO}_{3}$ and preclp1tated as the oxalate in the presence of reducing agents; (d) plutontum oxalate was redissolved in HNO 3 and oxldized to the hexavalent state by treatment with $\mathrm{NaBrO}_{3}$; (e) ether extraction similar to that used in the purification process described later (stepa $d$ and $e$ ), which involved extraction from acid solution (in the presence of amonium nitrate) and subsequent reduction with lodide and precipitation as the oxalate; and (f) after April 1945, the plutonium was extracted into ether and reduced to the tetravalent state and precipitated as the peroxide by addition of $\mathrm{H}_{2} \mathrm{O}_{2}$. The plutonium oxfde was converted to nitrate ( 4 valence state) and was given to the Dry Chemistry Group for fluorination. Late In 1944, the dilute supernatant solutions were reduced with $\mathrm{SO}_{2}$ and precipltated by treatment with $\mathrm{Al}(\mathrm{OH})_{3}$. In December 1944 , this process was turned over to another group (CM-10).

In retrospect, it ma'y be reasoned that the greatest exposures occurred in step e when $\mathrm{H}_{2} \mathrm{O}_{2}$ was added (with vigorous stirring) to high concentrations of plutonyl nitrate ( 1 to 40 grams per 11ter). Although this procedure was carried out in an open hood in 3-liter cooled beakers, there was considerable fizzing and discharge of droplets into the air outside the hood. In April and May 1945, this procedure was often carrled out by workers wearing respirators. (The number of high nose counts increased sharply when the peroxide step was added to the recovery procedure, but this also colnctded in time with the increasing amounts of plutonium being handled.) The addition of $\mathrm{NaOH}$ to the large vats of dilute supernatant solution $(0.1$ to 1.0 gram per liter) also caused heavy fogging and occasionally spatiering. Because of the size of the 50-1iter contalners, this procedure was carried out in the open laboratories without benefit of hoods. Other chemlcal steps which caused airborne contamination were concentratjing dilute solutions by bolling; ashing combustible materlals; and fusion procedures, especially those involving sodium peroxide plus carbon or persulfate.

As might be expected, in the atmosphere of excitement, tension, and fatigue that prevailed during the closing days of the war, the Recovery Group had its share of accidents which undoubtedly contributed to the exposures. The most dramatic of these occurred in May 1944 when the first 8-gram batch (the world's entire supply at that time) of purffled plutonium was being processed. An inftial 3.6-gram aliquot of plutony 1 nitrate in solution, placed in a glass thimble prior to Soxhlet extraction, was heated in an oven. As it was being removed, the glass cray supporting the thimble broke and the concentrated solution spilled on the floor. The spilled material was aspirated by mechanical suction, and the remaining plutonfum was recovered from the contaminated asphalt tile slabs torn up from the floor. When recovered and purified, this 
materlal was combined with more newly purified plutonium, and the 8-gram sample, in the lorm of the hydroxide, was placed in a centrifuge tube. While being centrifuged, the tube broke, spilling the sample into the centrifuge cup and in to the centrifuge itself. The plutonium was recovered once again by repeatedly washing the inside of the centrifuge with a dilute acid solution. $\star \star \star \star \star \star \star \star \star \star \star *$ Surprisingly, very little plutonium was lost in these two accidents.

In addition to these spectacular accidents, there were also occasional spiils of large volumes (up to 50 liters) of dilute plutonium solution ( 5 to $10 \mathrm{mg}$ ) onto the floor. (The smaller concentrated solutions were handled in stainless steel hoods.) Four of the 14 subjects cut their hands wi th contaminated objects; fortunately, in each case, the excised tissues contained little radioactivity. One other man burned his hand while carrying out the carbon-sodium peroxide fusion procedure.

As might be expected, exposures during the late spring and summer caused great concern about the health of these workers. The following excerpt is taken from the Monthly Progress Report of the Chemistry and Metallurgy Division for May 1945 (issued June 1, 1945):

"The health situation in the recovery laboratories has become much worse in the past month due to the great inciease in amount of product which is being processed. The trend in 24-hour urine counts is definftely upward. Because of this situation and because shutdown of recovery will essentially shut down purffication, as well as increase holdup of product, every effort is being made to improve the health situation. Forced afr respirators have been put into use, although they have not materially altered the nose counts yet. Contamina-

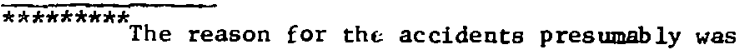
the unsuspected radiation-induced fragillty of the glass vessels used in these procedures. It was believed that alpha particles alone would not affect the glass, but Irradiation by neutrons arlsing from interaction of alpha particles with boron in Pyrex glass had not been anticipated.

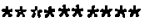

There is a story that great difficulty was encountered in the fluorination of this 111-fated batch of plutonium. We have not been able to verify this.
}

tion of the atr lines was suspected, but an investigation by $C M-12$ has $f_{c}$ led to show appreclable contamination. The air pressure is being increased. Better respirators must be obtained quickly. Improvements in the handling of product are being made, but it will be some time before the hazard can be appreciably reduced except by the use of better protective devices. $C M-1$ has helped with a number of improvements such as Installation of a new hood, studies on improving the ventilation, installation of foot-pedal sinks, etc. The situation is st11l critical, however."

All 14 subjects were removed in the sumer of 1945 from this type of work because urine assays Indicated that their body burdens were approaching or had exceeded the then maximum permissible levels (7 counts per minute per 24-hour urine spec1men, suggesting a body burden of $1 \mu \mathrm{g}$ or $0.06 \mu \mathrm{C} 1$ ).

\section{B. Purffication Operation}

Three of our subjects worked in the Purification Group in the Chemistry and Metallurgy Research Division. This group was given the responsibility of purifying by wet chemical methods the plutonium produced by the piles in oak Ridge and later in Hanford. Because it was believed that nonmetallic impurities could best be removed by subsequent dry chemistry procedures (see next section), this group concentrated on removing contaminating metals.

The flow sheet used in the purification operation $^{3}$ until July 1945 is shown in Fig. 6, Plutonium nitrate slurry received in 160-gram lots in metal containers from Hanford was dissolved, diluted (cut), assayed, and transferred (sometimes with considerable difficulty) into a closed syster. On the average, these preliminary steps took about 3.3 days. The following procedures were then carried out: (a) reducing $\mathrm{Pu}^{\mathrm{IV}}$ (or $\mathrm{Pu}^{\mathrm{VI}}$ ) nitrate wich lodide; (b) precipitating Pu ${ }^{\text {III }}$ oxalate and dissolving as $\mathrm{Pu}^{\mathrm{VI}}$ with bromate and nitric acid; (c) precipitating plutonium as sodium plutonyl acetate and dissolving in $\mathrm{HNO}_{3} ;$ (d) ether extracting plutonyl nitrate from the actd solution containing ammonium nitrate; and (e) reducing plutonyl nitrate with lodide and precipltating as the oxalate. Th1s product, recovered in about 97 percent yield, was given to the Fluorination Group. Purification of plutonium in this form continued to 


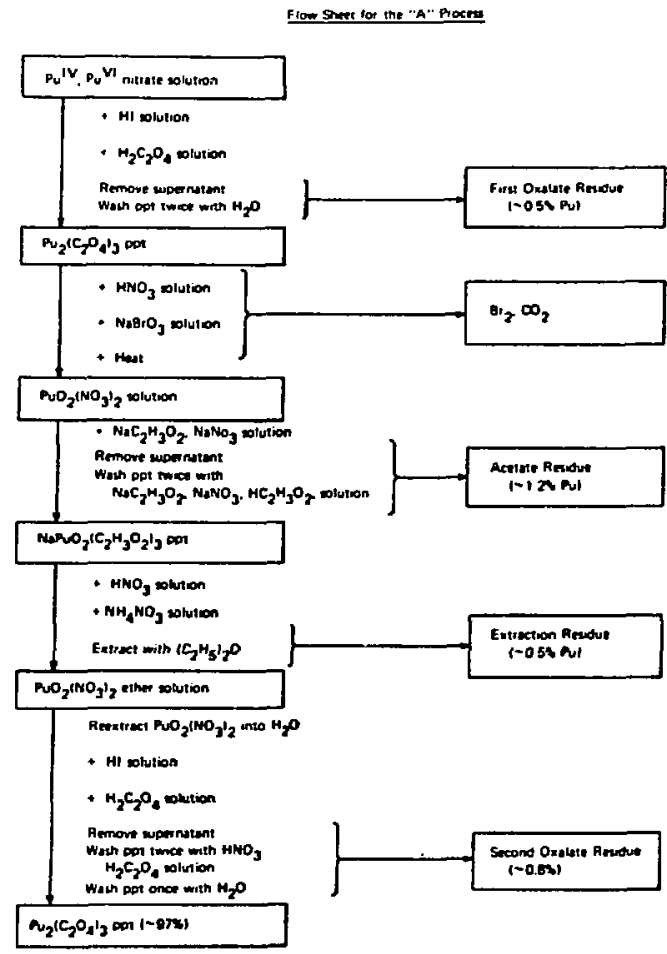

Fig. 6. Flow sheet for the purification operation. ${ }^{3}$

be carried out in D Building until September 1945.

Although this group handled 160-gram batches of plutonium totaling $4.9 \mathrm{~kg}$ in May $1945,5.69 \mathrm{~kg}$ In June, $6.13 \mathrm{~kg}$ In July, and $9.2 \mathrm{~kg}$ in August, the hazards to personnel were not as great as those in the Recovery Group. The nature of the operations (mainly decanting supernatant solutions from precipitates) was such thai they were quickly standardized and carried out in relatively simple closed systems. The body burdens of the 3 aubjecto in this group were consequently lower than those in the Recovery Group. Nevertheless, accidental exposures did occur. In August 1944, a vial contalning $10 \mathrm{mg}$ of plutonfum chloride in the +4 state exploded while being opened and heavily contuminated the face and mouth of a young chemist. Although the skin of the face was thoroughly scrubbed and the wouth thoroughly washed out, heavy contanination of the face (estimated to be $1 \mathrm{\mu g}$ ) persisted for several days. Frow the lonization of expired air. It was estimated that the level of contamination in the mouth was of the order of $10 \mathrm{\mu g}$. By blowing at an open-faced ionization chamber across the room, the subject could cause the needle to go off-scale. This man is well today and did not have a body burden of plutonium as measured by older urine assay methods.

\section{c. Fluorination Operation}

Three of the subjects with measurable body burdens of plutonium worked on this operation. Their job was to convert plutonium oxalate (prepared by the Purification Group) to oxide and then to fluoride prior to reduction to the metallic state. In the spring and summer of 1945, these men handled plutonium in batches of $160 \mathrm{grams}$ and worked in shifts around the clock.

Slurries of plutonium oxalate (from step 5 or 6 In the wet purification procedure) were poured into platinum boats and oxfdized by baking in a tube furnace within a hood. The uncovered boats, containing oxide in the form of a light green powder, were carried across the room to an ordinary analytical balance also in a hood. After being welghed, these boats were carrled back to a tube furnace in one of two large hoods with sliding glass doors and fired In the presence of hydrogen fluoride gas and oxygen. The plutonium fluoride was welghed and, if the conversion was not satisfactory, the fluorination procedure was repeated. Plutonlum tetrafluoride powder finally was poured into a glass container, covered, and passed on to the Reduction Group.

The 3 men working in the fluorination operation could have been exposed to plutonium dust in the form of oxalate, oxide, or fluoride. Some exposure presumably occurred while they were carrying or weighing the powdered plutonium even though respirators were always worn. Further exposure could have occurred when the wooden hoods were decontambuted (1.e., by scrubbing with scouring agents, painting, etc.). Fortunately, there were no serlous ac-1dents such as dropping a boat in the open laboratory.

\section{Reduction Operation:}

Three of the subjects worked in the metal reduction operation. They developed the methods of reducing plutonium fluoride to the metal, which was

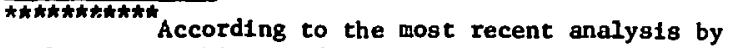
$\mathrm{J}$. Lawrence, this man does have a measurable body burden of plutonium. He is not but should be $a$ member of the UPPU Club.
} 
then fabricated into the shapes needed in the early atomic bombs.

Before plutonium became available in quantities, preliminary experiments were carried out using uranium and other metallic "stand-ins." The operators soon learned that reduction of plutonium and other metallic halides with alkali or alkaline earth metals was relatively easy but that, when operating on a small scale, the reduced metal tended to remain mixed with the cindery slag rather than to form well consolidated "buttons." (Since the melting point of plutonium was unknown at this time, the reaction vessels were considerably overheated, causing reacfions with the refractories.) While experiments were carried out to enable plutonium buttons to be produced on a larger scale in stationary bombs, the separation of plutonium from the slag was first successfully achieved by the use of centrifugal force to throw the molten metal into the tip of a cone-shaped container. This was called the "centrifugal bomb" method. $\mathrm{PuCl}_{3}$ or $\mathrm{PuF}_{4}$, mixed with lithium in a refractory cone-shaped beryllium oxide liner, was placed in an atmosphere of argon in a steel bomb about $1 \mathrm{in}$. in dianeter and $1-1 / 2 \mathrm{in}$. In height. This was welded shut and placed in an allgraphite centrifuge, heated electrically to $1100^{\circ} \mathrm{C}$ while being rotated. Good cohesive buttons were soon obtained. The first 500-mg metallic button of almost pure plutonfum ${ }^{5}$ was made by this method on May 26, 1944 (Fig. 7).

Although loading and unloading of the bombs

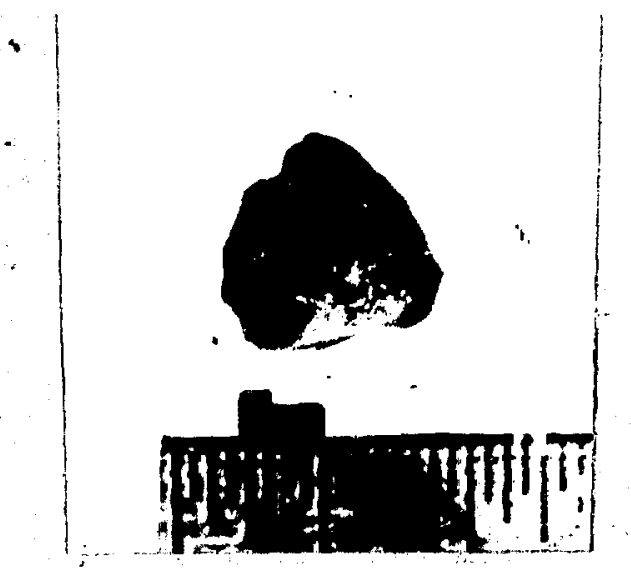

Fig. 7. A 500-mg metallic button of almost pure plut onium. were supposed to have been carried out In dryboxes, the welded steel bomb was difficult to saw open in such a confined space. On at least two occasions, certain procedures were carried out in the open laboratory. On one of these occasions, the nose count of one operator was 11,900 counts per minute, and the laboratory in which the work was carried on was heavily contaminated. This metallurgist and his assistant both have measurable body burdens of plutonium. ${ }^{* * * * * * * * * * *}$ In September 1944, this method was discontinued in favor of the "stationary bomb" method, which had been developed to the point where it was easier, quicker, and gave bet ter results than the centrifugal method.

The principle employed in the stationary bomb method was to pack a mixt ure of $\mathrm{PuF}_{4}$ and metallic calcium in refractory liners made of electrically fused Mgo contained in argon-filled steel bombs. On heating the bomb a strongly exothermic/thermic reduction reaction occurred, and the plutonium metal separated clearly from the fluid $\mathrm{CaF}_{2}$ slag. Addition of iodine to the charge helped ignition and improved collection efficiency. This became the standard method of reducing plutonium during the war. All loading and unloading operations were carried out in dryboxes. Because the lid was bolted on, disassembly of the bomb was easier than in the case of the welded bomb. Moreover, the well fused reaction products were less dusty than those in earlier small-scale experiments. Nevertheless, the metallurgist who developed this method does have a measurable t.ody burden of plutonium.

\section{EXPOSURE OF THE SUBJECTS}

By March 1945, the plutonium urinary assay method ${ }^{6}$ had been developed to the point where it could be applied to the plutonium workers. The assay system had to be extremely sensitive, as aata

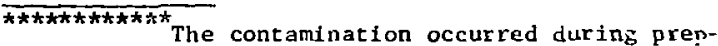
aration of the metallic button mentioned above. Unbeknown to their supervisors, these workers began the reduction at midnight. The next morning the plutonium button in an appropriate container was allegedly found on the desk of Dr. Cyril Smith, Associate Leader of CMR Division, and extensive contamination had occurred throughout the laboratory and adjacent hallways. The workers were nowhere around bue were finally located in the bar of the La Fonda Hotel in Sanca Fe, where they were celebrating their success in reducing plutonium by a technique they had developed.
} 
from animal experiments suggested that a person with a maximum permissibie body burden (at that time $1 \mu \mathrm{g}$ ) would excrete only $5 \times 10^{-5} \mu \mathrm{g}(50 \mathrm{pg})$ of plutonfum per day ( 7 alpha counts per minute or $50 \mathrm{pg}$ per 24-hour spectmen). Nevertheless, the assay method gave us our first hope of estimating how much plutonium had actually been deposited in the bodies of our workers.

Beginning on March 11, 1944, urine samples of members of the Recovery Group were assayed monthly or oftener. To the consternation of everyone, the radioactivity of the Initial 24-hour urine samples was of the order of hundreds of counts per minute, suggesting that the body burdens of plutonium were many times the acceptable levels. When a system of urine collection designed to minimize contamination of the urine specimens had been perfected (see Appendix B), the radioactivity of the urine sampies decreased precipitously. Table III shows early estimates of body burdens of plutonium based on urlne assays, as well as the number of high nose swipes (over 50 counts per minute) and total activ1ty of all high nose counts for each subject. 6 Although the correlation between the number of hIgh nose counts and body burden is not good, 8 of the 11 persons with more than $20 \mathrm{high}$ nose counts

TABLE III

RESULTS OF URINE ASSAYS AND NOSE SWAB COUNTS CONDUCTED ON LOS ALAMOS PLUTONIUM OPERATORS SHOWING PCSITIVE EXPOSURE

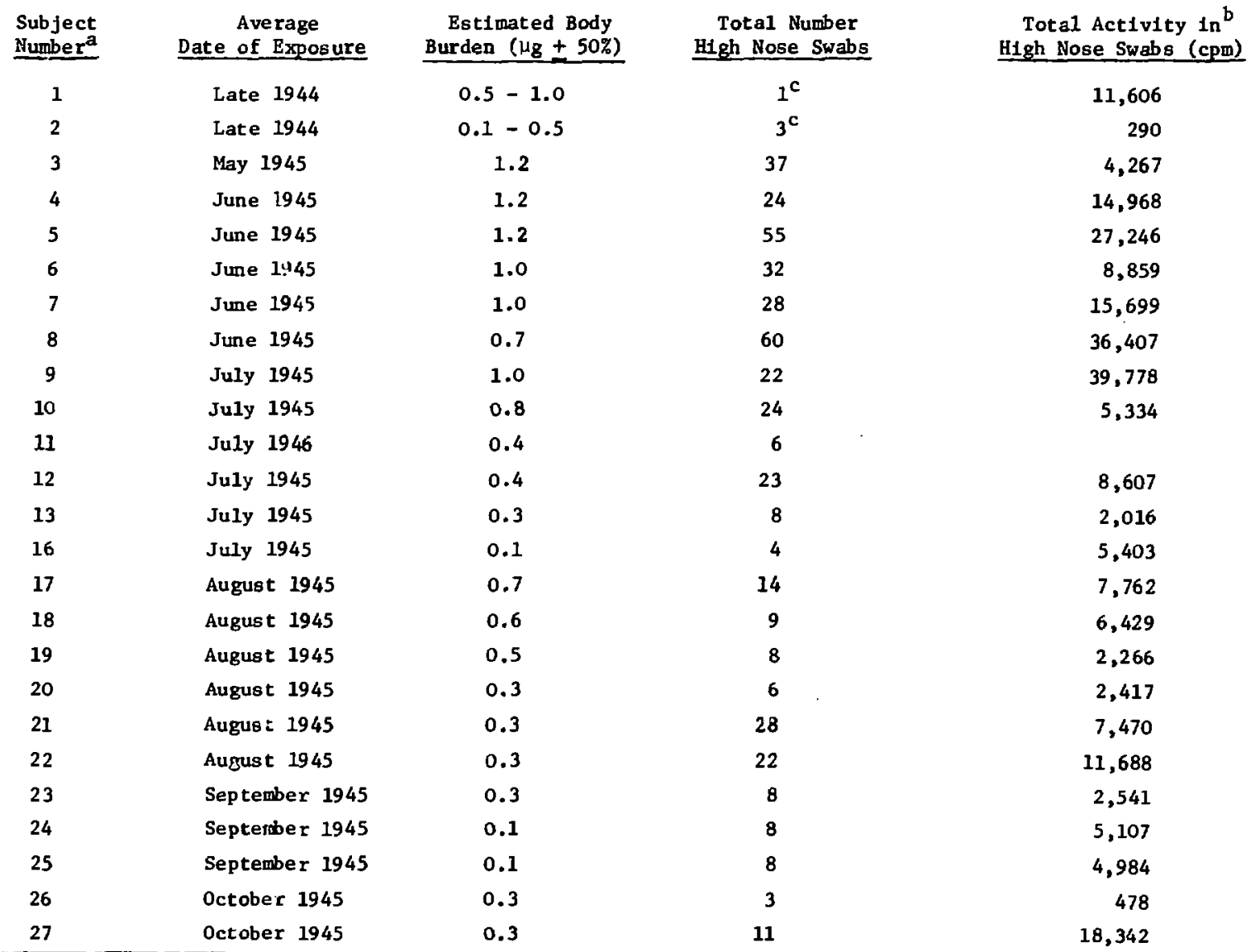

\footnotetext{
${ }^{a}$ Subject Nos. 14 and 15 were dropped because of the death of one subject of coronary heart disease and the low body burden of the other as determined by modern assay techniques.

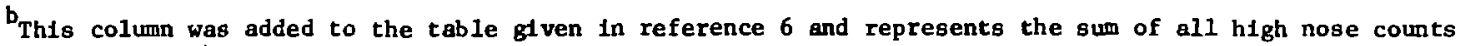
(both nogtrils).

Incomplete records were avallable for these cases.
} 
had a body burden of $0.5 \mu \mathrm{g}$ or more compared with 3 In 11 persons with lower levels. Furthermore, 6 of the 8 persons with total nose counts exceeding 10,000 counts per minute were in the former group.

In Fig. 8 the urine radioactivity, the number of high nose counts, and the total activity of the high nose counts per month of exposure of 8 subjects in the Recovery Group are correlated with the amount of plutonium processed and protective measures used. There was a sharp rise in plutonium excretion in 6 subjects (Nos. 3, 4, 5, 6, 9, and 17); in each case, the rise was preceded by a high activity of nose swipes, suggesting considerable exposure to airborne plutonium. There is no correlation between the level of body burden of plutonium as indicated by the urine radioactivity and total activity in the nose, but this is not surprising in view of the crudeness of the nose count techrique and the inevitable false positives due to contamination.

\section{CLINICAL, LABORATORY, AND RADIOACT IVITY OBSERVATIONS}

\section{A. Medical Observations}

In the early 1950's it was thought that 29 plutonium workers had measurable body burdens according to the assay methods of the time, but 3 have been dropped from the series as a result of the use of more reliable methodology, and one other died. In 1953, a program for periodic examlnation of these men (financed by the U. S. Atomic Energy Commission) was established. At first, a very thorough study every 2 years was planned. This included interval history and physical examinaticn, complete blood count, blood calcium, phosphorus and alkaline phosphatase, urinalysis, and stool examination for occult blood. The following roentgenograms were taken: lateral skull, PA chest, AP pelvis, AP of thee and elbow, lateral of foot, AP of foot, and dental films of right teeth.

In 1953 and again in 1955,22 and 25 subjects

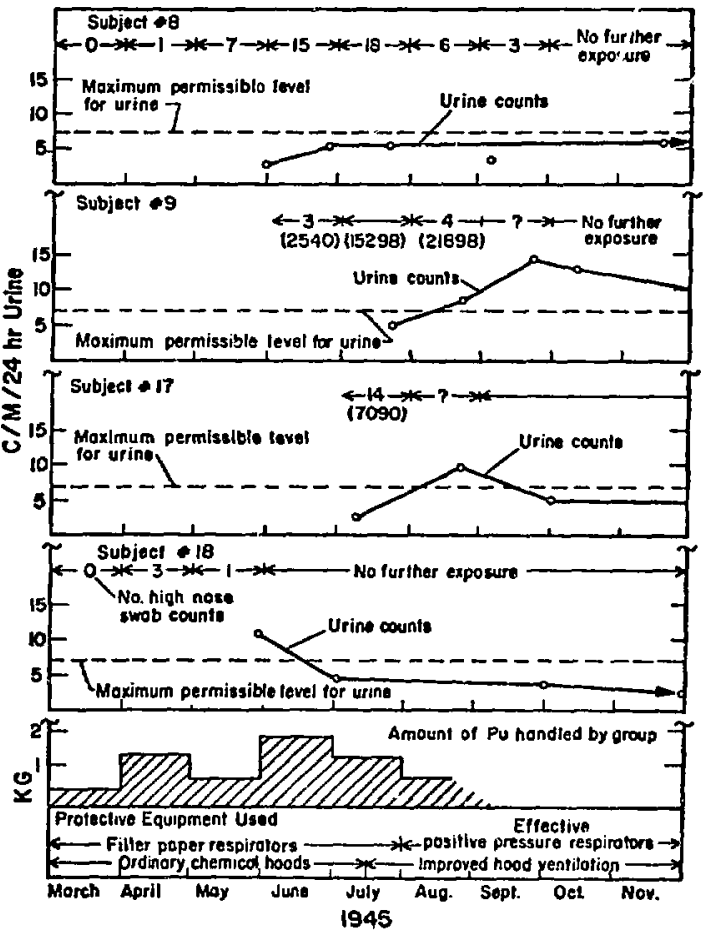

F1g. 8. Graphs for 9 subjects showing the urine count, number of high nose counts per month, and total radloactivity of nasal swipes per month (parenthetical figures) from March to November 1945. The amount of plutonium handled by the Recovery Group and the protective measures used are shown in the last graph of the second chart. 
of the series, respectively, were examined by physicians assoclated with the U. S. Atomic Energy Commission. There were no signiflcant medical findings, but some concern was expressed about what appeared to be an excess of bone islands in the roentgenograms. However, after careful comparison with normal male subjects of the same age, this observation was considered to be within normal limits. After reviewing the experimental program in 1956, it was decided to Increase the interval between examinations to 5 years and, on the advice of Dr. WIIliam Christiansen of the University of Utah, to reduce the number of $x$-rays. All 25 of the men were examined by their family physicians in 1960 , 17 in 1966, and 24 in 1970.

In late 1971 and early 1972,21 of the 25 subjects came to Los Alamos for a complete study including urine assays for plutoniun, in vivo measurements for ${ }^{239} \mathrm{Pu}$ in the chest, pulmonary cytology, and chromosome analyses. The medical examination consisted of the following procedures: complete history and physical, complete blood count, urinalysis and blood chemistry profiles (alkaline phosphatase, cholesterol, total bilirubin, total protein, albumin, globulin, A/G ratio, total lipid, SGOT, LDH, creatinine, glucose BUN, and urea). Roentgenograms were also taken of the chest, pelvis, and teeth.

Except for the aflments that one would expect In a group of men mostly in their early fifties, all subjects examlned were in remarkably good health. Ge man had a coronary occlusion but had recovered and was we11 compensated, and another of the original group died in 1959 of a coronary at age 38. Another had a hamartoma of the lung surglcally removed without complication in 1971 (see Appendfx $C$ and section $V . C)$. A third had a melanoma of the chest wall (reglonal lymph nodes were negative). A fourth had a partial gastrectomy for a bleeding ulcer. Several had mild hypertension and moderate obesity, and one had gout. All men were actively working, most as successful executives.

No roentgenographic changes in the lunge or bones were apparent. The lanina dura of the jaws (which show the first changes in beagles given toxdc doses of plutonium) vere intact in all cases except in o:e edentulous subject.
B. Plutonium Body Burdens as Determined by Urine Assay

The estimates of body burden of plutonium as determined by assay of the urine of the subjects made during the 20-year observation perfod (19531972) are shown in Table IV. Because more knowledge has been gained and techniques have changed completely since 1953 when the first reasonably sophisticated estimates were made, we have presented in Appendix $B$ a detailed description of the evolution of the methods of urine collection, radiochemical separation of plutonium, raciometric measurements, and the bases for estimation of the plutonium body burden. The current (1972) version of the PUQFUA (Plutonlum Body Burden From Urine Analysis) $\operatorname{code}^{7}$ was used to estimate what is considered to be the best value for the body burden of the

TABLE IV

PLUTONIUM BODY BURDEN ESTIMATES FOR IPPU SUBJECTS ${ }^{a}$

\begin{tabular}{|c|c|c|c|c|}
\hline $\begin{array}{l}\text { Case } \\
\text { Code } \\
\end{array}$ & $1953^{1}$ & $1957^{6}$ & $\underline{1962}^{7}$ & 1972 \\
\hline 1 & $0.03-0.06$ & $0.03-0.06$ & 0.01 & 0.206 \\
\hline 2 & $0.006-0.032$ & - & - & 0.03 \\
\hline 3 & 0.08 & 0.07 & 0.13 & 0.42 \\
\hline 4 & 0.08 & 0.08 & 0.14 & 0.26 \\
\hline 5 & 0.08 & 0.07 & 0.14 & 0.18 \\
\hline 6 & 0.06 & 0.06 & 0.07 & 0.14 \\
\hline 7 & 0.06 & 0.06 & 0.08 & 0.15 \\
\hline 8 & 0.04 & 0.04 & 0.05 & 0.11 \\
\hline 9 & 0.06 & 0.06 & 0.11 & 0.11 \\
\hline 10 & 0.05 & 0.05 & $n$, & 0.10 \\
\hline 11 & 0.03 & 0.02 & 0.03 & 0.05 \\
\hline 12 & 0.03 & 0.02 & 0.02 & 0.12 \\
\hline 13 & 0.02 & 0.02 & 0.04 & 0.005 \\
\hline 16 & 0.006 & 0.006 & 0.002 & 0.03 \\
\hline 17 & 0.04 & 0.04 & 0.09 & 0.13 \\
\hline 18 & 0.04 & 0.04 & 0.04 & 0.10 \\
\hline 19 & 0.03 & 0.03 & 0.06 & 0.02 \\
\hline 20 & 0.02 & 0.02 & 0.02 & 0.05 \\
\hline 21 & 0.02 & 0.02 & 0.03 & 0.04 \\
\hline 22 & 0.02 & 0.02 & 0.02 & 0.05 \\
\hline 23 & 0.02 & 0.02 & 0.04 & 0.04 \\
\hline 24 & 0.006 & 0.006 & 0.01 & 0.03 \\
\hline 25 & 0.006 & 0.006 & 0.01 & 0.01 \\
\hline 26 & 0.02 & 0.02 & 0.03 & 0.006 \\
\hline 27 & 0.02 & 0.02 & 0.03 & 0.05 \\
\hline
\end{tabular}

Microcurie \pm approximately 50 percent. 
subjects. Assay of replicate urine samples was used as the basis for the values in Table IV. In the last column, all data acceptable to the PUQFUA code were used. In all but 2 cases, the current estimates of body burden are higher than those in 1953, usually by a factor of 2 to 3 and sometimes by a factor of 5 to 6 . Since each figure is based on a number of assays ranging from 5 to 125 for different subjects, some values are considered to be firmer than others. There is uncertainty in these values, espectally those based on relatively few assays, because of the Inevitable errors in extrapolating the excretion curve back to the time of exposure many years before (see Appendix B).

The values shown in the last column of $\mathrm{Ta}$ ble IV range from 0.005 to $0.42 \mathrm{LCi}{ }^{239-240} \mathrm{Pu}$, or from approximately $1 / 8$ to 10 times the current max1mum permissible body burden $(0.04 \mu \mathrm{C} i$ ) for occupational workers. Eighteen of the 25 values listed for 1972 are equal to or exceed the $0.04 \mu \mathrm{Ci}$ value. In 1962, only 12 of the 25 subjeus were thought to have body burdens exceeding $0.04 \mu \mathrm{Ci}$. To test the validity of the values for body burden based on urine assay, we have compared the estimates based on urine assay of case No. 2 with that calculated from radfoactivity of the rib removed prior to lobectomy. The latter estimate is crude, as $1 t$ involves a large extrapolation and assumes uniformity of distribution of plutonfum throughout the entire skeleton. For a 7000-gram skeleton, the plutonium content would be $11.27 \mathrm{nC}$. If the liver content was of the same order of magnitude (not an unreasonable assumption), then the body burden in these two organ systems which contain most of the radioactivity (excluding lung) would be about $22 \mathrm{nc1}$. The estimated body burden for case No. 2, based on urine assay (Table IV), was $30 \mathrm{x} 1$. Most probably the excellent agreement is fortultous.

Comparing the minute quaritities of plutonfum deposited in the body (excluding the lungs) with the large amounts to which the subjects had been exposed, we can only conclude that the gastrointestinal tract has a remarkable ability to exclude plutonium from enterlang the body. Had plutonium been as readily absorbed as radium, all subjects would unquestionably have lethal body burdens of radioactivity.

One of the first references to estimates of the body burdens of the subjects included in this report is found in the 1952 annual report of the Biomedical Research Group of the LASL's Health Division. I The basic information given in this report (with one ninor change which may have been a transcriptional error) appeared in another report the following year, ${ }^{6}$ together with information on nose swabs, as shown in Table III. In 1962, Lawrence ${ }^{7}$ updated the Langham estimate of the body burdens on the basis of additional urinary assay data collected just prior in 1962. Lawrence used a computational mode1 called PUQFUA ${ }^{8}$ which, although based on the Langham metabolic model, was programed to eliminate certain data points believed to be uncertain. On the average, the 1962 PUQFUA estimates of body burden for the 25 subjects were 1.6 times those estimated earlier by Langham. The differences anong the values (shown in Table IV) are not surprising, as Lawrence's numbers were based upon nore data collected over a longer time period, and his computer system was programmed to select the data to be used in the analysis (e.g., criterla for excluding data points are built into the PUQFUA code). Short discusstons of the plutonium body burdens of the UPPU subjects also appeared in several other publications by Langham and colleasues. 9,10

Some data for the early ios Alamos subjects appeared in 1969 in a document published by Langham. ${ }^{11}$ The first 12 cases in Langham's table, shown in our $\mathrm{Tab} l e \mathrm{~V}$, are members of the UPPU club. Of added interest is the fact that accumulated average organ doses included for bone, 11ver, and lung were estimated using the total radiation doses from time of exposure until the late 1960's. These dose estimates were based on metabolic models recommended by the International Comission on Radiological protection. It is interesting to note that the estimared average accumulated doses in bone were less than 18 rads in all subjects. S1nce plutonium is concentrated on the perfosteal and endosteal surfaces rather than uniformly distributed in bone, the dose to Individual osteocytes may be considerably higher than this. The average liver dose was estimated to be up to 5 times higher than the bone dose.

To evaluate the possible consequence of bone doses of this magnitude, we must refer to animal data, particularly that in dogs given plutonium intravenously. The oldest and most extenstve of 


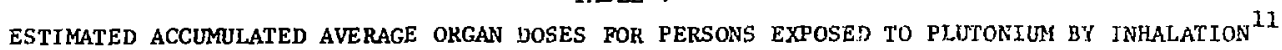

\begin{tabular}{|c|c|c|c|c|}
\hline Time since Exposure & Estimated Exposure & $\frac{A c}{2}$ & lated Average & Dose $^{a}$ \\
\hline (years) & $-(\mathrm{MPL})^{\circ}$ & Bone (rads) & Liver (raas) & Lung_(x \\
\hline 24 & 1.4 & 6.7 & 37 & 80 \\
\hline 24 & 1.4 & 6.7 & 37 & 80 \\
\hline 24 & 1.6 & 7.6 & 42 & 90 \\
\hline 24 & 1.8 & 8.6 & 47 & 100 \\
\hline 24 & 2.0 & 9.6 & 53 & 110 \\
\hline 24 & 2.3 & 11.0 & 61 & 130 \\
\hline 24 & 2.5 & 12.0 & 66 & 140 \\
\hline 24 & 3.3 & 16.0 & 87 & 190 \\
\hline 24 & 3.4 & 16.0 & 90 & 10. \\
\hline 24 & 3.6 & 17.0 & 95 & 200 \\
\hline 23 & 1.1 & 5.0 & 28 & 63 \\
\hline 23 & 1.1 & 5.0 & 28 & 63 \\
\hline
\end{tabular}

\footnotetext{
These values are being brought up-to-date using the latest values for the body burden. This is a subject of a future report.

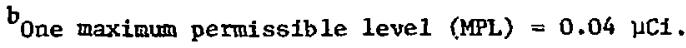

these studies has been carried out at the University of Utah Medical School. ${ }^{12}$ On December 1, 1952, the first group of 6 beagles were injected (IV) with ${ }^{239} \mathrm{Pu}$ citrate. Injected doses ranged from 0.016 to $2.9 \mu \mathrm{Cl}$ per $\mathrm{kg}$ body weight for 6 groups of about 12 dogs each. The first animal to die in July 1956 of an osteogenic sarcoma was in the hIghest dose group. In 1961, an osteosarcoma occurred in a beagle at the then lowest dose $(0.016 \mu \mathrm{Ci}$ per $\mathrm{kg})$, and since then several lower dose groups have been added to the experiment. The lowest dose group, $0.00064 \mu \mathrm{Ci}$ per $\mathrm{kg}$, corresponds roughly to the maxImum permissible occupational body burden $(0.04 \mu \mathrm{CI})$ in man.

To date, the $0.016 \mu \mathrm{CI}$ per $\mathrm{kg}$ dose level is of Interest, as 4 dogs have developed osteosarcomas, giving a tumor incidence of 33 pexcent. The average time from injection to death for these animals was 9.9 years, and the average skeletal dose from injection to death was estimated to be about $80 \mathrm{rads}^{13}$ (a more recent estimate suggests about 50 rads). We do not know whether osteosarcomas will. be produced at dose levels lower than $0.016 \mu \mathrm{Cl} / \mathrm{kg}$ and can only awalt the outcome of this important experiment. However, we do know that the tumor Incldence decreases and the time required for tumors to develop increases as the anount of plutonium
Injected is reduced. These observations have prompted numerous investigators to predict no adverse blological effects (e.g., practical threshold) below certain levels of injected plutonium. This point has not been accepted by everyone and has not been proven unequivocally for alpha-emitting radionuclides. 14

\section{c. Determination of Plutonium in the Body by In Vivo Measurements}

1. Plutonium in the Chest Cavity. Durlag the most recent (1ate 1971-early 1972) medical examinations at IOS Alamos, estimates were made of the amount of plutonium in the lung and resplratory lymph nodes of each subject using an in vivo lung counter (see Appendix D). Figure 9 shows the pair of detectors in position for counting the low-energy $x$-rays emerging from the chest. Measurements also were made of the liver region in several subjects and of the hands of persons known to have had skin wounds contaminated by plutonium. The minimum detectable activity (MDA) for human subjects measur with the LASL detectors varies with several parameters such as body build and chest thickness. An average IDA for a 2000-second counting time is abuut 7 nCl if one uses the 95 percent confidence level. For the 68 percent confidence level and a similar 


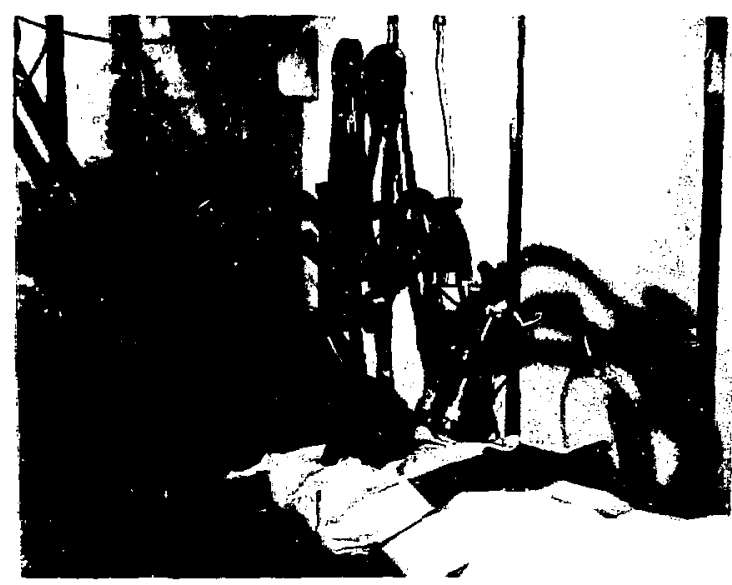

Fig. 9. The in vipo counter with detectors in position for counting the chest.

counting time, the comparable value is about $3.5 \mathrm{n}$ Ci.

Positive counts were obtained for 14 of 21 persons measured. These counts suggested chest burdens ranzing from 3 to about $10 \mathrm{nCi}$. However, in no case did the est amated chest burden exceed the MDA at the 95 percent conf:ience level. Seven of the 14 subjects with positive chest counts had estimated chest burdens of $7 \mathrm{nCi}$ or greater and may be considered (at the 68 fercent level of confidence) to have statistically significant chest burdens of from 7 to $10 \mathrm{nCi}$. For reference, $10 \mathrm{nCi}$ is about $2 / 3$ of the maximum permissible lung burden for occupational workers ( $16 \mathrm{nCl}$ ). if maintained indefinitely, this burden will deliver about 15 rem per year to the lung, assuming uniform distribution of energy throughout the organ.

$1 f$ one uses the 68 percent confidence level, certain qualitative statements can be made about the chest measurements. For example, the estimates of lung burdens of subject Nos. 1 and 2, who most likely recelved exposure to plutonium oxida, were approximately to $\mathrm{nCi}$. Subject Nos. 4 and 9 , who worked In the Recovery Group, each had a chest burden on about $8 \mathrm{nci}$. These relatively sma:l values are not surprising, in view of the known cranslocation of plutonium from the lung to other tissues as a function of time following inhalation.

The cumulative radiation doses to the lungs of some of our subjects have been estimated previously by Langham ${ }^{11}$ (Table V). The values, all less than 200 rads, are below the lowest doses which caused adverse biological effects seen in experiments using beagles. For example, Bair and colleagues at Battelle-Northwest have not observed lung effects below about 2000 rads in dogs 10 to 12 years following a single inhalation exposure to ${ }^{239} \mathrm{PuO}_{2} \cdot{ }^{15}$ However, these animal data must be interpreted with caution, as lung tumor incidence is essentially 100 percent at the lowest plutonfum exposure levels.

Recently beagles have been exposed to lower initial alveolar depositions, but additional data on the dose-response function will not be available for many years. The estimated initial alveolardeposited plutonium in beagles which developed lung tumors ranged from 0.2 to $3.3 \mathrm{HCi}$ per total organ, or about 3 to $45 \mathrm{nCi}$ per gram of bloodless dog lung. Park and his associates ${ }^{16}$ estimate that this amount of plutonium is 100 to 1500 times the estimated maximum occupational lung burden in man (i.e., $0.016 \mu \mathrm{Ci}$ or about $0.03 \mathrm{nCi}$ per gram of bloodless lung). As a conservative estimate based upon extrapolation of their data to the 15-year mean life span of beagle dogs, these authors feel that initial deposits of about $70 \mathrm{nCt}$ in the lung (about $1 \mathrm{nC} i$ per gram), which cause premature death in beagles, are about 30 tines the concentration equivaient to the maximum permissible occupational lung burden for man. This concluston, of course, is based on the assumption that lung tumor development is related to plutoninm concentration and not to the total amounc of plutonium in the lung. For example, if tumor induction is someiow related to the total number of cells at risk (therefore, the number and size of plutonium particles), then the relative sizes of human and dog lungs may be unimportant and the $70 \mathrm{nCi}$ which causes premature death from lung cancer in the dog may be about 5 times the total amount of plutonium (70/16) considered to be the maxfmum occupational lung burden for man. 18

The experimental data obtafned from rodents are not as clear nor as encouraging. Moskalev 17 reports that the frequency of malignant neoplasms of the lungs of rats exposed to plutonium by inhalation is 2 or 3 times higher than in the control group at doses ranging from 41 to 234 rads. Noskalev states that, assuming the bological effect 
is independent of the distribution of dose in time, we must accept a dose of 75 rads (accumulated over 50 years of occupational exposure) as inducing malignant tumors and pulmonary sclerosts. 17 In man, Langham ${ }^{11}$ estimated 100 rads to the lurig as a completely empirical judgment as to a level "at or above which biological consequences may ensue in a small population of limited distribution."

Park and co-workers at Battelle-Northwest report that the plutonium content of the thoracic lymph nodes of beagles was about the same as that of the entire lung tissue about 5 years following a single inhalation exposure. 16 At this time, both lung tissue and thoracic lymph nodes contained about 30 percent of the initial alveolar-deposited ${ }^{239} \mathrm{PuO}_{2}$. At about 10 years following exposure, the lungs contained about 12 percent and the thoracic lymph nodes about 40 percent of the initial alveolar-deposited ${ }^{239} \mathrm{PuO}_{2}$. From these data, we might expect a signiffcant fraction of the original lung burden of our human subjects to be present in the thoracic lymph nodes many years after exposure to plutonium oxide. However, one must exercise caution, as we do not know whether the translocation rates of plutonium oxide are the same for the beagle and man or whether the rates otserved for beagles with large lung burdens would be realistic for amaller initial alveolar deposits in man. Although a single measurement of ${ }^{239} \mathrm{Pu}$ in the chest of subjects exposed 27 to 28 years ago is of little help in obtaining accurate estimates of the current chest burdens, simtlar periodic measurements on several recently exposed individuals have ylelded data on temporal changes of plutoniun within the chest. Had repeated, periodic measurements been made on the present subjects, we would have more confidence in our estimates of the chest burden.
The only direct measurement of plutonium in the lungs in this study was made on the operative specimens of subject No. 2. Table VI shows results of analyses for ${ }^{239} \mathrm{Pu}$. The concentration of ${ }^{239} \mathrm{Pu}$ was approximately the same in the tumor and lung tissue, while the concentration of ${ }^{239} \mathrm{Pu}$ in bone was approximately half. The highest concentration, observed in the lywph node tissue, is consistent with the experimental findings in dogs exposed to $\mathrm{PuO}_{2}$ by 1nhalation, as mentioned above. It is well established that the concentration in lymph nodes relative to that in lung tissue increases as a function of time following exposure. If one assumes a homogeneous distribution of ${ }^{239} \mathrm{Pu}$ throughout the lung and lymph ncies and a total lung weight of 1000 grams and respiratory lymph node welght of 20 grams, the total plutonium burden of the lungs and respiratory lymph nodes is approximately $8 \mathrm{nCi}$ roughly equally divided between lung and $1 \mathrm{ymph}$ node. For reference, the total amount of plutonium in the lung of case No. 2 (estimated by tissue assay to be $3.85 \mathrm{nCi}$ ) is approximately 550 times contemporary total lung burdens in humans in the United States exposed to fallout resulting frow plutonium dispersed by atmosphertc weapons tests. Estimates of the chest burden of ${ }^{239} \mathrm{Pu}$ of subject No. 2, based on extrapolation from analysis of 1 ung and lymph node tissue, are in reasonable agreement (a factor of about 2) with estimates based on chestcounting. Figure 10 shows an autoradiograph of a pluconium particle in a section of lymph node removed from subject No. 2. Observations of other plutonfum particles in the lymph node tissue examined indicate a very nonuniform radiation dosedistribution from plutonium particulates,

2. Plutonium in other Tissues. Because we have no rellable calibration system for plutonium

TABLE VI PLUTONIUM-239 CONTENT OF TISSUES REMOVED FROM PATIENT NO. 2 IN MAY $1971^{a}$

\section{Tissue}

Lung

Lymph node

Hamartoma

RAb

a

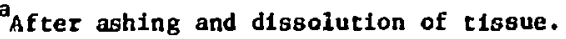

We: Welght
(grams)

70.85

1.25

0.77

20.00

\begin{tabular}{|c|c|}
\hline Volume & $\begin{array}{l}\text { of Solution } \\
\text { (m1) }\end{array}$ \\
\hline & 100 \\
\hline & 25 \\
\hline & 25 \\
\hline & 100 \\
\hline
\end{tabular}

Plutonium-239 (dpm per ml) (dpm per gram) ( $\mathrm{pC} 1$ per gram)

$\begin{array}{rrr}\text { (dpm per ml) } & \frac{\text { P1utonium-239 }}{\text { (dpmper gram) }} & \\ 6.01 & 8.48 & 3.85 \\ 22.55 & 451.00 & 205.00 \\ 0.23 & 7.47 & 3.40 \\ 0.71 & 3.55 & 1.61\end{array}$




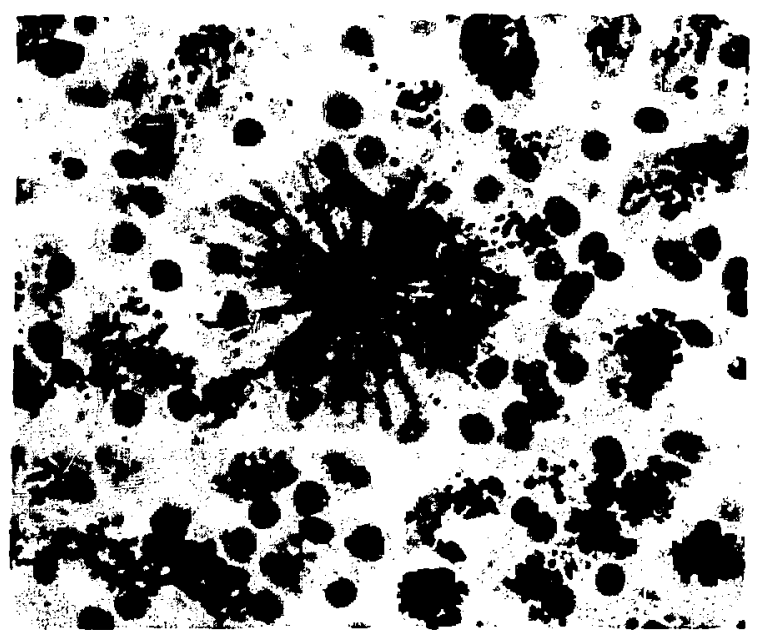

Fig. 10. Autoradiograph of lung section of subject No, 2 showing a radioactive particle.

in the liver of human subjects, we can make no quantitative statements concerning the observations in several persons who were measured. Plutonium within the bone cannot be measured by the in vivo counting technique. Traces of plutonium were decected by counting the hands of several subjects known to have hand wounds while working with plutonium in 1944 or 1945. The site was precisely located in one case (subject No. 1) and the amount estimated to be $5.3 \pm 0.4 \mathrm{nCl}$. Of interest is the observation that the subject erroneously thought that the wound was on the other hand. At present, the skin overlying the active site appears to be grossly normal except for minimal scaling. We plan to make additional measurements on and observations of this deposit in the future.

\section{Chromosome Analysis}

During the 1971-1972 visit to the LASL, blood samples were obtained from the UPPU group for chromosome studies using standardized, established techniques. Although no abnormallties were found in these subjects, we plan to add newly developed chromosome banding techniques to our procedures when the group is next studied.

During recent years, considerable interest has been directed at the effects of various stressing agents on chromosomes of lymphocytes in the pertpheral blood. The induction of chromosomil aberrations in juman peripheral leucacytes has been studied in persons exposed to ionizing radiation as well as to a variety of exogenous agents such as cyclamates, caffeine, and LSD. More recently, the effects of elements such as cadmium that are environmental pollutants suspected of contributing to himan disease ${ }^{18}$ have been studied. Radiationinduced human chromosome aberration yields have been used to estimate radiation doses received by people involved in radiation accidents involving whole-body exposure to ${ }^{60} \mathrm{Co} .19$ Similar studies have also been performed on peripheral blood leucocytes obtained from subjects exposed years ago to Thorotrast; 20,21 the element ${ }^{232}$ Th decays through 6 alpha and 4 beta disintegrations to ${ }^{3} 08 \mathrm{~Pb}$ (about 90 percent of the radiation energy is associated with high LET alpha rays). Radium daughter products deposit in bone, thoron is exhaled, and consequently both bone and lung tissue are irradiated. Finally, the chromosomes of blood lymphocytes of patients with body burdens of radium have been analyzed; many of these patients were exposed prior to World War II. 22,23 In both Thorotrast and radium patients, marked excesses of chromosome aberrations were reported.

Because of observations of chronic lymphopenia in dogs exposed to plutonium oxide aerosols, one might expect to observe chromosome damage in lyuphocytes of exposed plutonium workers. This observation led Dolphin ${ }^{24}$ to investigate the possibility of chromosomal aberrations in lymphocyte cultures obtained from workers in England known to have been exposed to plutonium. He compared the findings in 8 plutonium workers who had been exposed to plutonium plus 14 rads of external irradiation over a 7year period with workers who had received external irradiation only and found that the dicentric yield of lymphocytes of the plutonium workers could be accounted for by the extemal radiation dose recelved by the workers. Dolphin ${ }^{24}$ also cites another case in whicl a plutonium worker was found, by chest-counting, to have 10 to 20 times the permissible level of plutonium in the lung about 3 years after an inhalation accident. Chromosome analysis indicated minimal radiation damage to the lymphocyte series even at a high level of exposure of the patient. Other livestigators are studying chromosomes obtained from uranium miners exposed to a vartety of stressing agents, including radiation, 
during their employment. However, one must use caution when interpreting quantitatively results obtalned from chromosome analysis, as the number of aberrations cannot continue to increase with the accumulated dose because of the finite life span of the lymphocyte. For long periods of chronic exposure, one would expect a constant equilibrium level of aberrations.

\section{E. Cytology of Exfoliated Bronchial Cells}

Sputum cytology lias been used by Saccomanno 25

as a possible indicator for detecting inciplent or actual lung cancer in uranium miners exposed to radon daughters and other stressing agents in uranium mines. Because lung cancer has been observed experimentally in animals exposed to plutonium aerosols, we have added the cytological examination of bronchial cells to our periodic studies of the UPPU Club members. In a few subjects, moderate to severe dysplastic changes have been observed. The significance of these changes is not clear except in one man who was a heavy cigarette smoker (3 packages per day). We are now in the process of developing standardizid procedures for collecting and preparing sputum samples. This presents a sizable problem, since our subjects live in different parts of the country often without easy access to large medical centers.

Since exposure to tobacco smoke and other toxic materials is known to alter the normal cytology of bronchial cells, it is difficult to interpret the observed effects. Primarlly for this reason, we have asked all of our subjects to give up smoking. There is also a need to develop a standardized nomenclature to be used in reading and reporting sputum specimens. At periodic intervals, we will send bottles containing flxative for collecting sputum samples to each subject, who will then return the samples to us for analysts. If anyone shows more chan a moderate cellular atypla, he will be asked to submit samples more frequently. We w1ll also obtain sputum samples for cytological examination from local nonexposed personnel of the same age and smoking hablte for purposes of comparison.

\section{CONCLUDING REMARKS}

This report attempts to reconstruct the exposure conditions of LOS Alamos plutonfum workers during World War II and gives factual data on estimated body and lung burdens of plutonfum, as well as medical and laboratory findings. A more comprehensive interpretation of these data will be the subject of a future report.

\section{ACKNOWLEDGMENTS}

This work was done with the support of the U. S. Atomic Energy Commission, Division of Biomedical and Envi ronmental Research, under Contract AT-(30-1) 4284 to the School of Medicine and Dentistry, University of Rochester, and under Contract $W-7405-E N G-36$ to the University of California, Los Alamos Scientiflc Laboratory.

This report covers information and work that has been carried out over a period of many years and has involved many persons who have contributed to the success of the project. The special contributors have all played a prominent part in data collection or analysis in their particular specialty. The analytical urinalysis procedures were done by E. Campbell, M. Milligan, and W. Moss at the Occupational Health Laboratory, LASL. J. Lawrence calculated the current body burden values by means of the PUQFUA program. Roentgenographic studies were made by P. Lee, M.D., Los Alamos Medical Center, and W. Christiansen, M.D., Department of Radiology, University of Utah. In vivo measurements of plutonium within the lung were performed by $P$. Dean at the Health Research Laboratory, LASL. Pulmonary cytology studies were made by G. Saccomanno, M.D., Pathologist, St. Mary's Hosp1tal, Grand Junction, Colorado, and Michael Stewart, M.D., Pathologist, LOB Alamos Medical Center, Los Alamos, New Mexico. D. Petersen, Health Research Laboratory, LASL, assisted in procuring the samples for pulmonary cytology. The chromosome studies were performed by D. Petersen at the Sealth Research Laboratory, LASL. H. Whipple, M.D., Industrial Medical Group, LASL, directed the physical examination portion of the study, including clinical laboratory measurements. J. Healy, LASL Health Divislon, gave constructive criticisms in his review of the manuscript.

Many other persons coo numerous to mention have contributed importantly to the work. A special acknowledgrent is extended to J. Langham for photographic and autoradiographic work; H. Ide for 
assistance in the in vivo chest measurements; P. Flynn, M.D., for medical examinations; 0 . Johnson for assistance in administrative arrangements; and D. Meyer for his help in recalling exposure cond1tions and health safety procedures in the early days.

\section{REFERENCES}

1. W. H. Langham and J. B. Storer, Eds., "Annual Report of the Biomedical Research Group of the Health Diviston, 1952," Los Alamos Sctentiftc Laboratory report $\mathrm{LA}-1537$ (June 1953), p. 8.

2. G. T. Seaborg, "Health Hazards in Working with Plutonium," Memorandum to R. S. Stone, report MUS-GTS-399 (January 5, 1344).

3. "The Chemistry of Plutonium," Los Alamos Scientiflc Laboratory Technical Sertes report LA1100 (1947), downgraded to Confidential in 1959.

4. W. H. Langham, "Determiration of Plutonium in Human Urine," Los Alamos Scientific Laboratory report LAMS-603 (December 1947); also U. S. Atomic Energy Commission report MDDC-1555, Technical Information Division, Oak Ridge, Tennessee (March 1945).

5. C. S. Smith, "Plutonium Metallurgy at Los Alamos during 1943 to 1945," in The Metal PIutonium, A. S. Coffinberry ard W. N. Miner, Eds. (University of Chicago Press, Chfcago, I11., 1961), Chap. IV, p. 30 .

6. L. H. Hempelmann and W. H. Langham, "Determination of Systemically Deposited Plutonium in Laboratory Personnel and a Simple Qualitative Test for Exposure to Airborne Radioactive Material" (U. S. Atomic Energy Commission, Technical Information Service, Oak Ridge, Tennessee, December 1953), report AECU-2633.

7. J. N. P. Lawrence, "PUQFuA, An IBM 704 Code for Computing Plutonlum Body Burdens," Health Phys. 8, 61 (1962).

8. J. N. P. Lawrence, "PUQFUA: An IBM-704 FORTRAN Code for Determining Plutonlum Body Burden from Urine Assays," Los Alamos Scientific Laboratory report LA-2329 (April 1960).

9. W. H. Langham, "Physiology and Toxicology of Plutontum-239 and Its Industrial Medical Control," Health Phys. 2, 172 (1959).

10. W. H. Langham, J, N, P. Lawrence, J. McCle1land and L. H. Hempelmann, "The Los Alamos Scientific Laboratory's Experfence with Plutonium in Man," Heal th Phys. 8. 753 (1962).

11. W. H. Langham, "BLological Considerations of Nonnuclear Inc1dents Involving Nuclear Warheads," J. F. Becker, Ed., Univera1ty of California Radiation Laboratory report UCRL50639 (April 1969).
12. C. W. Mays and T. F. Dougherty, "Progress in the Beagle, Studies at the Universicy of Utah," Health Phys. 22, 793 (1972).

13. C. W. Mays, G. N. Taylor, W. S. S. Jee, and $T$. F. Dougherty, "Speculated Risk to Bone and Liver from 239 Pu," Health Phys - 19,601 (1970).

14. C. W. Mays and R. D. Lloyd, "Bone Sarcoma Incldence vs. Alpha Particle Dose, in Radiobiology of Plutonium, B. J. Stover and W. S. S. Jee, Eds. (The J. W. Press, University of Utah, Salt Lake City, Utah, 1972), p. 409.

15. W. J. Bair, "Inhalation of Radionuclides and Carcinogenesis," 1t. Inhalation Carcinogenes1s, M. G. Hanna, Jr., P. Netteshein, and J. R. Gilbert, Eds. (U. S. Atomic Energy Commission, Diviston of Technfcal Information, Washington, D. C., April 1970), AEC Symposium Serles 18, p. 77.

16. J. F. Park, W. J. Batr, and R. H. Busch, "Progress in Beagle Dog Studies with Transuranfur Elements at Bartelle-Northwest," Health Phys. 22, 803 (i.772).

17. Y. I. Moskaiev, "239 Pu: Problems of Its Biological Effect," Health Phys. 22, 723 (1972).

18. Y. ShIratsh 1 , H. Kurahash 1 , and T. H. Yosida, "Chromosomal Aberrations in Cultured Human Leucocytes Induced by Cadmium Sulfide," Proc. Japan Acad, 48, 133 (1972).

19. J. G. Brewen, R. J. Preston, and $L$. G. Lfttlefield, "Radiation-Induced Human Chromosome Aberration Ylelds following an Accidental Whole-Body Exposure to $60^{C o} \gamma$-Rays," Radiation Res. 49, 647 (1972).

20. M. L. Janower, O. S. Mettinen, and M. J. Flyan, "Effects of Long-Term Thorotrast Exposure," Radiology 103, 13 (1972).

21. P. Fischer, E. Golob, E. Kunze-Mueh1, and T. Muellner, "Chromosome Aberrations ln Persons with Thorium Dioxide Burdens," In Human Radiation Cytogenetics, H. J. Evans, W. M. Court-Brown, and A. S. McLean, Eds. (NorthHolland Publishing Company, Amsterdam, and J. W1ley and Sons, Inc., New York, 1967), p. 194.

22. R. Tuscany and J. Muller, "Chromosomal Study of Bone Marrow and Peripheral Blood in Persons Carrying Body Burdens of ${ }^{226} \mathrm{Ra}$ and ${ }^{90} \mathrm{Sr}$," in Human Radiation Cytogenetics, H. J. Evans, V. M. Court-Brown, and A. S. McLean, Eds. (North-Holland Publishing Company, Amsterdam, and J. Wiley and Sons, Inc., New York, 1967), p. 203.

23. J. T. Boyd, W. M. Court-Brown, G. E. Woodcock, and $J$. Vennart, "Relationsh1p between Externa1 Radiation Exposure and Chromosome Aberrations among Luminous Dial Palnters," In Human RadiatIon Cytogenetics, H. J. Evans, W. M. CourtBrown, and A. S. McLean, Eds. (North-Holland Pub 11shing Company, Ams terdam, and $\mathrm{J}$. Wiley and Sons, Inc. New York, 1967), p. 208. 
24. G. W. Dolphin, "The Biological Problems in the Radiological Protection of Workers Exposed to 239 Pu," llealth Phys. 20, 549 (1971).

25. G. Saccomanno, R. P. Saunders, V. E, Archer,
O. Auerbach, M. Kuschner, and P. A. Beckler, "Cancer of the Lung: The Cytology of Sputum prior to the Development of Carcinoma," Acta Cyto1. 9, 413 (1965). 
APPENDIX A

DECONTAMINATION PROCEDURES AND RESPIRATORS USED AT LASL IN 1944

The following is an excerpt from a Secret letter written by L. H. Hempelmann to Dr. Robert S. Stone, Cilnton Laboratorfes, Knoxville, Tennessee, dated July 20, 1944, which describes decontamination procedures and respirators:

"1. Desontamination Procedures:

A. Floors: A special corp of janttors assigned to these laboratortes spend all their time on this job. They work under the supervision of a head fanitor and a

"laboratorian." In order to get good resuits and to keep the floor counts low, it is necessary for the floors to be covered with a smooth hard surface of wax. There does not seem to be much difference in the kinds of wax that we used so we have settied on the water-soluble floor wax supplied by the fanitor service. Our present floors are made up of some asphalt tiles known by the trade name of "Mastic." In some new laboratories we plan to use a smooth asphalt surface with an Mgo base.

1. Routine Cleansing: All floors are mopped once a day; floor of hot laboratories are mopped twice a day or oftener. They are wet mopped with a gond lather of Ivory soap, followed closely with a dry (wrung out) mop. It is essential that the janitors be meticulously careful about covering the entire floor. The results are better if the wash and rinsing water be kept separate. By this method it has been possible to keep the floor counts i a most labs below 100. In our "hottest" laboratories, the counts are always below 500. We are now using some detergents in an effort to ohtain better results.

2. Decontamination after Spillage: This is done by a trained decontamination squad. The floor is first mopped with Ivory soap. The wax is then removed with boiling hot water, followed by kerosene and steel wool. The floor is then painted with two coats of any thick paint which w111 stick to the surface.

B. Desk Tops of Laboratory Benches: Every work1ng surface is covered with a smooth surface preferably glass. Porous surfaces are covered with enamel paint before they are used for work. If they are contaminated by accident, an effort is wade to seal them in the material by painting rather than to remove the contaminated part of the desk top. In the case of the lab benches made of "Kemrock" (the ordinary black surface made by the Kewaunne Mfg. Co.., Adrian, Mich.) the surface responds to ordinary methods of decontanination although it appears to be porous. The same company puts out a surface paint of the same material, called "Kemrock Wipe Coat," which can be used to paint over contaminated surfaces.

1. Routine Cleaning: Smooth surfaces can be quite successfully decontaminated by wiplng with a clean cloth wet with spindle ofl. An excess of o1l $1 \mathrm{~s}$ used and this is followed by a clean dry cloth. The secret of the successful use of this method is to change cloths very frequently. The surface count is usually reduced below 50 per minute by this method.

2. Decontamination after Spillage (or after contamination from droplets produced by evaporation): First wipe the surface with 1 N HCl solution followed by dry rag, then clean with olled rag as above.

C. Hands: Before starting work, spread thin coating of spindle ofl over both hands; this must be done very carefully. Decontaminate gloves before removing them; remove gloves using gurgical technique so as not to touch outside surface with hands. Apply coat of West's Sulfo soap to hands, molsten with water and lather, rinse; repeat with Sulfo soap and finally wash with Ivory soap. 
The success of this method depends upon how vell directions are followed particularly insofar as spindle oll is reapplied after each washing of the hands. It has been our experience that it is usually possible to reduce the hand counts to a few hundred or less by means of this method.

D. Gloves and Respirators: A 10 percent solution of the detergent "aerosol" 15 used for decontamination of rubber articles. Other detergents do not seem to work as we11. The solution containing acetic acld formerly used by us has been discontinued because the acid tended to infure tite rubber and was hard on the skin if not properly removed. The gloves are washed every day (after one wearing). They are rubbed and swished arourd in the solution unt1l clean. This is quite time consuming as about two minutes is required for each glove (we hope to cut this down by getting each person to decontaminate his own gloves after wearing). The rubber respirator facepieces are cleaned once a week if their count is over 50 .

E. Glassware: This is cleaned by running each plece of glassware through the following solutions :

1. water

2. Ivory soap water followed by rinsing

3. cleaning solution followed by rinsing

4. Ivory soap and water followed by rinsing

5. dist11led water

Popham says that the results seem to be satisfactory but he will not guarantee them. Not very much work has been done on this problem.

F. Tools: Can be decontaminated with an ofled rag as described above. Uge clean cloths and clean frequent:ly.

2. Masks: We have used only Wilson respirators and positive pressure masks. Most of the respirators put out by this company have filter pads which are satisfactory for this type of dust. Their chlef disadvantage is in their fallure to fit properly but we have found that one of the following three types will fit just about any type of face: $200 \mathrm{~L}$, SL and 750 . We are careful to fit each mask to the person before letting then go into use. As far as the positive pressure masks are concerned we have not tried the A.M.S. type because they did not appear as satisfactory as the Wilson type as described in their catalogies. We have trodified the masks by putting on softer tubing onto the facepiece since there were some complaints about the gtiff tubing supplied by the company and by placing the filters on the wall rather than on the belcs. The tubes are fastened to the belts to avoid the masks being jerked off the faces of the men if the tubing gets caught. We have still not been able to put the positive pressure masks in general usage because of the crowded conditions in our laboratories.

The Eastman masks which I described to you over the telephone appear to be the most satiafactory of all, but have not been well tested. If you see them and consider having some made up we would be very interested in placing an order at tie same time."

Declassified by L. M. Redman (September 11, 1972) 
APPENDIX B

URINE ASSAY METHOD AND ESTIMATION OF BODY BURDEN

URINE SAMPE COLLECTION

Beginning in January 1944, spot urine samples were collected from plutonium workers in the hope that measurement of plutonium in the urine might yield results which could be related to exposure to and/or Intake of plutonfum. By March 1944, a procedure had been adopted whereby urine samples were collected on a 24-hour basis in so-called "clean" areas, but the data derived from analysis of urine samples suggested occasional massive artifactual contamination. To minimize the possibility of such contamination, a Health Pass Ward was established In the Los Alamos Hospital in the spring of 1945. Each employee heavily exposed to plutonium was granted 2 days off with full pay ${ }^{*}$ prior to reporting to the hospital, where he stayed for 24 hours. During this time, an uncontaninated or ounimally contaminated 24-hour urine sample was collected using all practical procedures to minimize contamination. Upon entering the Health Pass Ward, the men showered and changed into hospital pafamas, which were wom throughout the collection period. White morticlan's gloves were use: while collecting the uriue specimens.

Table I shows the rather striking differences recorded for urinary excretion of plutonium in 6 subjects who collected urine samples both at hove and in the hospltal. The data are shown on origInally presented by Wright Langham at a plutonium conference in May 1945 and documented in a report

\footnotetext{
Employees, particularly those in milltary service. were forever grateful to Langhat for the 2-day leave away from ti.e "HIll," as the mesa was called. $\pitchfork \star$

'Langham's favorite story had to do with the enormous quantities of urine passed by many of the plutonium worlere while in the hospltal ward. The subjects, ueually G. I.' $s$, were able to obrain beer from the ncorby PX by some means and drank this in substantial quantities. Fortunately, plutonium output is Independent of quantity of urine. According to Langham, the champion was a man nicknamed Pias Porter (not his real name).
}

TABLE I

EFFECT OF METHOD OF COLLECTING SAMPLE ON COUNTS FOUND IN THE URINE

\begin{tabular}{ccc} 
Subject & \multicolumn{2}{c}{ Place of Collection of Sample $(\mathrm{cpm})$} \\
\cline { 2 - 3 } 6 & $\frac{\text { At Home }}{\text { An Hospital }}$ \\
3 & 10.1 & 2.2 \\
4 & 41.6 & 4.3 \\
C & 16.1 & 3.4 \\
C & 2.8 & 0.1 \\
5 & 17.8 & - \\
& 30.6 & 2.2 \\
Average & 20.0 & 2.2
\end{tabular}

\footnotetext{
${ }^{\text {a }}$ Samples collected at home were 2 overnight voldings collected by the individual after thorough bathing and washing of hands.

bamples collected In hospital were 24-hour sarmles collected under the rigorous hospital plan after a 2-day leave from the "H111."

Got in UPPU follow-up.
}

In Tune 1945. I Unfortunately, this problem of sample contamination during collection has been forgotten periodically (e.g., operational exposures and accidents such as Palomares and Thule), and this has led to misinterpretation of data.

Also of incerest is another table (Table II) from the aame report, ${ }^{1}$ which gives some information on the then current average urine blanks of 0.5 count per minute (per 24 hours) and recovery volues for the urine assay procedure. In the early days, data were of ten presented as counts per minute. The efficiency of the proportional counter used at the time 1s uncertain but probably approached 50 percent.

In an effort to minimize costa, the procedure was modified in 1947 to eliminate the 2-day health paso period, but the employee still reported to the 
TABLE I I

RECOVERY OF KNOWN AMOUNTS OF PLUTONIUM FROM REGULAR AND MOCK URINE SAMPLES

\begin{tabular}{|c|c|c|c|c|}
\hline $\begin{array}{c}\text { Number of } \\
\text { Deteruinations }\end{array}$ & Nature of Samples & $\begin{array}{l}\text { Amount of Splke } \\
(\mathrm{cpm}) \\
\end{array}$ & $\begin{array}{l}\text { Recovery } \\
(\%) \\
\end{array}$ & $\begin{array}{c}\text { Spread } \\
(\%) \\
\end{array}$ \\
\hline 24 & Blanks (regular urine) & 0.0 & (average $0.5 \mathrm{cpm}$ ) & $(0-1.2 \mathrm{cpm})$ \\
\hline 4 & Mock urine solution & 29.2 & 94 & $88-100$ \\
\hline 11 & Mock urine solution & 10.0 & 93 & BS-101 \\
\hline 12 & Regular urine & 10.0 & 88 & $73-104$ \\
\hline 3 & Regular urine & 4.5 & 95 & $81-105$ \\
\hline
\end{tabular}

Health Pass Ward for sample collection. In a further effort to reduce costs, the Health Pass Ward was abolished in 1951, and employees were asked to collect at home 2 roming and 2 evening voidIngs. These samples were pooled and considered the "equivalent" 24-hour urine sample. A reusable metal kit was furnished the employee; each kit contained three 1-pint bottles, which were discarded after use. The metal kits proved eventually to be unsanitary, and the concept of collecting 4 voldIngs in three bottles proved unacceptable. Therefore, a disposab ie cardboard kit containing four 1-pint bottles was introduced in January 1958; a statistical review of the results obtained $1 y$ analysis of samples collected by this means suggests that a "true" 24-hour sample is not necessarily collected. The pooled samples represent the urine voided over a perlod of $22 \pm 4$ hours when collected correctly. Thts collection procedure is used today.

Since 1969, occastonal nonroutine samples have been collected in speciai containers with time marks on the lids in an effort to leam more about the constancy of plutonfum urinary excretion. Information galned from analysis of such timed samples has made it posstble to apply corrections by volume and specific gravity so that results expressed in disintegrations per minute per sample can be realistically corrected to disintegrations per minute per day.

RADIOCHEMICAL SEPARATION METHOD OF URINARY ASSAY TOR PLUTONIUM

To the best of our knowledge, as of January 194\%, urine samples were ashed and the alpha activity ot the ash was measured directly. ${ }^{2}$ However, we know that in 1945 urine samples were ashed and the plutonium separated by co-extraction with an ironcupferride complex. Existing tata from that time suggest that plutonium recovery was $B 2 \pm 19$ percent assoclated with blanks of $0.69 \pm 0.53$ disintegration per minute. By 1949, the serial bismuth phosphate-lanthanum fluoride co-precipitation technique was in use, affording rezovertes of $67 \pm$ 20 percent with blanks of $0.15 \pm 0.1$ disintegration per minute. In 1955, an alkaline earth phosphate precipitation was used directly on urine samples to concentrate plutonium, eliminating the need to evaporate large volumes of urine. This change in procedure did not alcer the measured recoveries or blanks.

The desire for greater sensitivity resulted in adoption in 1957 of the Hanford procedure. In this method, plutonfum is separated by TTA extraction, and the final radiometric measurement is made by NTA (nuclear track alpha) film counting. The Hanford procedure afforded plutonium recoveries of $70 \pm 17$ percent with blanks of $0.007 \pm 0.005 \mathrm{~d}$ is Integration per minute. A somewhat simpler radiochemical separation procedure utllizing anton exchange was substituted in 1963 . Introduction of electronic equipment capable of pulse-height discrimination made it posstble in 1967 to include a step utflizing ${ }^{236} \mathrm{Pu}$ as a tracer or yleld-deteminer. In June $1972,{ }^{242} \mathrm{Pu}$ was substituted for ${ }^{236} \mathrm{Pu}$ to reduce the background in the ${ }^{238} \mathrm{Pu}$ and ${ }^{239-240} \mathrm{Pu}$ regions. The procedure, In use today, afforda an overall recovery of $80+20$ percent as determilned by internal spiking with ${ }^{236} \mathrm{Pu}$ (or ${ }^{242} \mathrm{Pu}$ ).

\section{RADIOMETRIC MEASUREMENT}

The measuring device used In 1944 ras a gas flow proportional alpha counter of unknown efficiency 
with a background of approximately 30 counts per minute. Simpson gas flow proportional counters, acquired in May 1945, were operated orf.ginally with an efficiency of 48 to 50 percent and a background of about 1 count per minute. Modifications of these counters, chiefly lining the counting chamber itself with electrolytic copper foil, reduced the background to $0.15 \pm 0.1$ count per minute. These counters, in continuous use until 1957, were supplemented in 1952 by four NMC gas flow proportional counters operating at 48 to 49 percent efficiency with backgrounds of about 0.1 count per minute. The NTA procedire, aojoped in January 1957, involved the counting of microscopic tracks instead of electronic detection. This gave a background of 0.005 count per winute wh an efficiency of 50 percent. The overall procedure had a sensitivity limt (50 percent confidence level) of about 0.05 disintegration per minute per sample. From Apr11 1966 to January 1967, zinc sulfide scintillation counters were used; these devices were about 45 percent efficient with a background of $0.01 \pm 0.006$ count per minute. Aicquisition of alpha spect rometric equipment in 1966 led to measurement of all samples by alpha spectrometry after January 1967; the procedure yields an efficiency of 27 percent and a background of $0.004 \pm 0.003$ count per minute. In use presently is an 8-detector system with electronic data processing capability, which allows one to measure simultaneously isotopes of ${ }^{236} \mathrm{Pu},{ }^{238} \mathrm{Pu}$, 239-240 $\mathrm{Pu}$, and ${ }^{242} \mathrm{Pu}$.

In addition to techniques such as alpha spectrometry and proportional counting, plutonium can be measured also in the urine by a track etch procedure following neutron 1rradiation. In the latter system, neurrons are used to produce flssion fragments, usually in a thick plastsc waterial supporting the plutontum-containing sample. The damaged areas of the plastic are then etched and can be quanticated by use of optical means or spark counters. ${ }^{3}$ Although not in wide use at present, this system is sald to offer a considerable improvement over others in terms of sensitivity.

\section{EST IMATES OF BODY BURDEN FROM BIOASSAY TECHNIQUES}

Urtne assay data are used as the basis for determining the body burden of Intermally deposited plutonium. In more recent times, computer programs have been written to relate urine assay data to the body content at a given time after contamination or at the time of contamination. However, whether one resorts to the convenience of computerized data reduction and analysis or to hand calculations as practiced in the early days, the procedures are based, at least in part, upon the systemic model of urinary elimination developed by Langham and colleagues." This model was derived from data obtatned from studies of human subjects of short 1 ife expectancy. These persons were given plutonium citrate by intravenous injection in 1945. 5 Langham used these data to derive a simple power function equation to relate urinary excretion rate to body content. The power function 1 s often used to approximate a set of exponential functions characterized by both decreasing the amount and release rate from various compartments. More recent analyses of the data from the orfginal patients and from industrial exposures suggest that eithe: the power function or multiple exponential functions can be used to fit the observed excretion patterns. 6 Although most of the human data were obtained during the first 140 days after injection, some information is avaflable for excretion periods up to 5 years. Use of power functions based on the lat ter data give the following specific expressions for rates of urinary and urinary plus fecal excretion In man given plutonium citrate over a period of 5 years:

$$
\begin{aligned}
E R_{u} & =0.002 t^{-0.74} \\
E R_{u+f} & =0.008 t^{-0.94} .
\end{aligned}
$$

where $E R_{u}$ and $E R_{u}+f$ represent the fraction of the injected dose excreted per day and the days following exposure.

Following a single exposure at a known time, one can estimate the body burden (Q) at time of exposure from measurement of a 24-hour urine specimen collested at a later time (t). Using Eq. 1 and the relation

$$
E R_{\mathbf{u}}=U / Q
$$

where $V$ is the awount of plutonlum measured in a 24-hour urine sample at time $c$, then 


$$
\mathrm{Q}=500 \mathrm{vt} \mathrm{t}^{0.74}
$$

Substitution of known vaiues for $t$ and $U$ ailows one to estimate total-body burden at time of exposure in the same units that are used for $U$ (i.e., count rate, mass, or activity). Similarly, the body burden $\left(Q_{R}\right)$ at any time $t$ following repeated exposure may be calculated by using the total elimination coefficient and assuming multiple inputs as a summation process.

A major difficulty in evaluating human exposures has been the problem of reservoirs of plutonium in various organs (not bone) that are slowly released to the circulatory system at rates that depend on many factors such as location within the body, particle size, and physiochemical form.

This slowly translocated plutonium is subsequently deposited in other tissues and ultimately lost from the body via urinary and fecal excretion.

The concept of slow, continuous release of bound plutonium into the body fluids, first formalized by Healy, ${ }^{7}$ has been bullt into models by several groups of investigators. 8,9 The rate of urinary or fecal excretion of plutonium in persons chrontcally exposed can be estimated from Eqs. 1 and 2 by summation of Individual admfnistrations. Healy's model regards relatively insoluble plutonium in the lung as a reservolr isolated from normal body metabolism yet continually releasing plutonium into the bloodstream. The model has no constraints regarding the position of plutonfum in any portion of the lung or body; therefore, particles translocated from the lung to lymph nodes behave in the same manner as those in the lung, provided the rate of solution and entry into the systemfic circulation is the same. The model. assumes a constant fractional removal per unit time from the lung and then utilizes the systemic model developed by Langham. 10

The quantity $(Q)$ in the lung at time $t$ following scute deposition after inftial clearance of an amount $\left(Q_{0}\right)$ of insoluble plutonfum 1s:

$$
Q=Q_{0} e^{-\lambda t}
$$

The overall elimination rate $(\lambda)$ actually represents both solubilization and transfer to the systentc clrculation and discharge from the lung by clliary clearance mechanisms. One can then describe transfer to the systemic circulation as:

$$
a=\lambda_{s} Q_{0} e^{-\lambda t}
$$

Assuming that each increment transferred is excreted according to the function shown in Eq. 1 , the total excretion may be described as the sum of the excretion rates from each increment. Time $(t)$ is relative to elapsed time since transfer from the lung rather than time since inhalation. Using $R$ as the time urine samples are obtained after inhalation, the excretion rate $\left(E_{u}\right)$ is:

$$
E_{u}=0.002 \lambda_{s} Q_{0} \int_{0}^{R} e^{-\lambda t}(R-t)^{-0.74} d t .
$$

Unfortunately, Eq. 7 is not integrable and must be solved for individual values of $\lambda, R$, and $t$ by expansion of the exponential term and solving until the series converges. The overall transfer rate ( $\lambda$ ) was thought to be composed of two components: (1) rate of transfer into the systemlc clrculation $\left(\lambda_{s}\right)$, and (2) rate of loss via ciliary clearance mechanisms $(\lambda)$. Healy assumed that $\lambda_{s}$ was the same as $\lambda$. Simtlar expresstons were dertved for fecal excretion and for the amount of plutonium in blood.

Figure 1 shows the calculated relation between

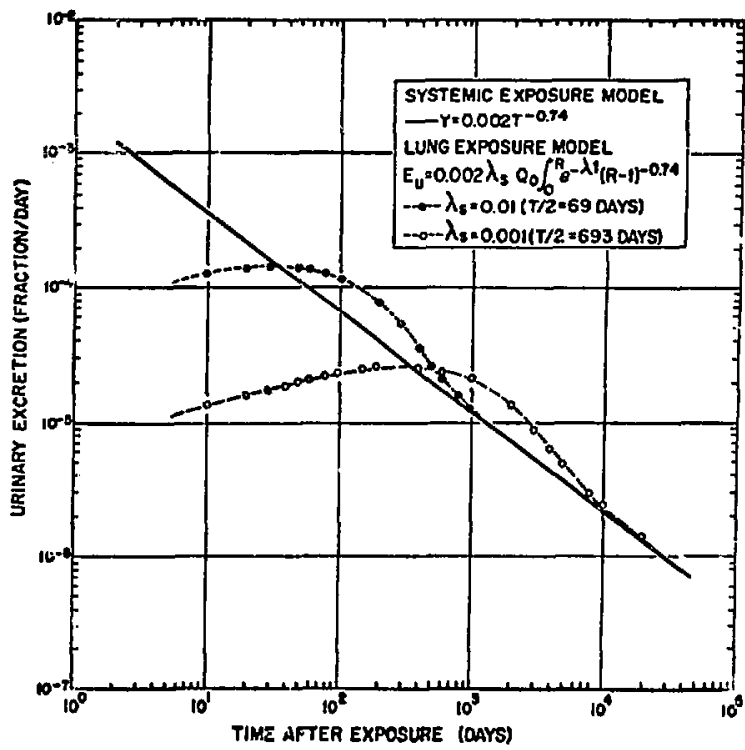

Fig. 1. Fractional urinary excretion as a function of time after acute exposure based on the systemf $c$ and lung exposure models. 
predicted urinacy excretion rate and time, assuming various rates of exponential clearance from a nonsystemic reservolr. ${ }^{11}$ The solld line represents the systemlc exposure madel (no transfer from the lung) which is the bas is of the PUQFUA computational model. 12,13 Even for slow luag clearance $t$ imes (e.g., 693-day balf clmes), the lung modei and the systenc model both yield similar urinary excretion values at $10^{4}$ days, which corresponds to about 27 years following exposure. It is important to appreciate that these are ldealfzed curves which are used as the bases for estimating plutonium body burdens. In real life, except for persons with industrial exposures who sometimes can be followed closely during esployment, urine samples can be obtaited only at relatively infrequent times. This is also true in the case of some UPPU Club menters who, although exposed in 1944 or 1945, provided relat i-cly few urine samples during the latervening 27 years. To date, the number of urine samples used to estimate body burdens for the subjects of this study have ranged from 5 to 125 for different ind $1-$ viduals.

\section{REFERENCES}

1. W. Langham and E. R. Russe11, "Excretion Studies," In "Report of Conference on Plutonium -- May 14th and 15th, 1945," J. J. Nickson, Ed. (CIInton Laboratory), report $\mathrm{CN}-3167, \mathrm{p}-27$.

2. E. E. Campell, M. F. Milligan, W. D. Moss, and ii. F. Schulte, "History of plutoniun Bioassay Program at LASL, 1944-1972,"LOS Alamos Sc1entific Laboratory report LA-5008 (September 1972).

3. E. I. Hamilton, "The Registration of Charged Particles in Sollds: An Altemative to Autoradiography in the Life Sclences," Int. J. Appl. Radiat. Isotopes 19, 159 (1968).

4. H. H. Lingham, "Determination of Internally Deposited Rodioactive Isotopes from Excretion Analyses," Amer. Ind. Hyg. Assoc. Quart. 17. 305 (1950).

5. H. H. Langham, S. H. Bassett, P. S. Harris, and R. E. Carter, "Distributior and Excretion of Plutontum Adatisistered Intravenously to Man," Los Alomos Scientific Laboratory report LA-1151 (September 1950).

6. F. W. Durb1n, "Plutonium in Man: A TwentyFive Year Review," University of California Radiation Laberatury report UCRL-20850 (June 1971).
7. J. W. Heaiy, "Estimation of Plutonfum Lung Burden by Urine Analysis," Amer. Ind. Hyg. Assoc. Quart. 18, 261 (1957).

8. S. A. Beach and G, W. Dolph1n, "Deterwination of Plutonium Body Burdens from Measuresents of Dally Urine Excretion," In Assessment of Rad1oactivity in Man (Intemational Atomic Energy Agency, VIenna, 1964), Vol. II, p. 603.

9. W. R. Woot, Jr. and W. E. Sheehan, "Evaluation of the PUQFUA Method of Calculating Systemic Burdens," Amer. Ind. Hyg. Assoc. J. 32. 58 (1971).

10. W. H. Langham, "Excretion Methods, The Application of Excretion Analyses to the Determination of Body Burden of Radloactive Isotopes," Brit. J. Rad101. Suppl. 7. 95 (1957), Yart $v$.

11. W. H. Langian, "Phystological Properties of Plutonive and Assessment of Body Burden in Man." In Assessment of Radloactivity in Man (International Atoric Energy Agency, Vienna, 1964). Vol. II, P. 565.

12. J. N. P. Lawrence, "PUQFUA: An IBY-704 FORTRAN Code for Determining Plutoniun Body Burden from Urine Assays," Los Alamos Sc1entif1c Laboratory report LA-2329 (Apr11 1960).

13. J. M. P. Laurence, "PUQFUA, An IBM 704 Code for Computing Plutonfun Body Burdens," Health Phys. 8, 61 (1962). 
APPENDIX $C$

MFDICAL FOLLGH-UP o: PATIENT No. 2

Beginning in the spting of 1942, patient No. 2 was exposed to uraniur halldes whlle atcerpting to reduce uranium tetrafluoride to the actallic state. Patlent No. 2, one of several nonnilleary peebers of the UPPU group, worked at Los Mlamos fron February 3. 1944, to August 16, 1944. He subsequently vorked at other Installat lons where he was not exposed :0 radloace 1 ve macerlals. However, lace in 1946, he was erposed to beryl11us oxide and beryllius chloride. In 1948, he was engaged in hot-pressing uranius porder with hardening agents. In 1952, he worked with catalytie agents but had ne significant exposure to toxic chealcals. In 1954, he was exposed to sodiun vapore as well. as compounds of chlorine, arsente, and antiwony. Very often these waterlals were weighed in the open in eruelbles that were evacua ed and then fired. The crucibles were opened withour the benefit of hoods or dryboxes. In 1960, he worked with cadmitur selenite in a vacula system but probably uas not exposed to toxic anzerials. Since 1965, he has been Involved In the anufacture of electronic instrments used to detect hydrocarbons.

Durlag the medical exanination in 1966, a small, coin-sized lesion was noted in the right lower lung. A previous chest roentgenogram ande in $196 n$ had been nortal. The follow-up examination In 1969 confliced the lung abnotmallty which showed no detectable change ii slze. In a roentgenograv taken in March 1971, the lesion had nearly doubled In size and then had an outsida diameter of about $5 \mathrm{~cm}$. Failowing consultation between at tending physlelans, the Individual concemed, and ataff of the AEC'B Division of Blology and Hedicine, the patient was adnteted on Hay 4, 1971, co a large hospltal in the eatem United States for further diggostc studies. Durling the following sereral daya, he was subjected to a serles of diagnostic rests Ineluding pulmonary funcelon, sputu cycology, tanealus lrsufflation, bronchoscopy, and Iung tocography. Cytological erasinations based on spucun, bronchoscoplc washings, and brush specimens shored no petaplasia in cells exfollated from the bronchial trec. There were sose Indieations of an Inflamatory process which could be cozpatble with an underlyling bronchial growth. Toxographic tests verified the previous findings of a vell demarcated, siaple leston located in the righe loser lung. Fibcr-optic bronchoscopy indicated no abnorwal changes in the lung with small branchioles (to about $3 \mathrm{ga}$ ). Cytological study of specioens obealned by plnch blopsy was also negat Ive. Results of the cantalus Insufflation radiography Indicated so Intrusion on the bronchlal tree or deposition defects.

Because of the desonstrable growth of the lesion since 1965 , the attending physiclans decided to perform a siaple lobectosy, and on thy 17, 1971, the right. lower lobe was rewoved. Itistclogleal sectiono of the twor and reglonal lymph nodes vere ade, and sexplec of the tumor. tornal lung. reglonal lyoph nxdes, and bone vere sent to several laboratorles for radloactive asaay and rafsographlc seudles. Hiscologically, the neoplasa was a classical benlgin hrierecue (derived from residisal emoronic cells) contalning considerable adulc cartilaginuus and ep1theisal cells. Interestingly, the regionul lywph nodes were perfectly notas histologienlly with no signs of cellular damage desplte the relatively high radioactivicy.

Patlent No. 2 is currenty in good health and returned to Los Alawos with other cembers of the UPPU broup fo: addiclonal atudy In November 1971. He believe if is vorthuhlie to polnt out that there 1s concern and interest for these subjects cven though many years have pasaed olnce thcy worked with 
plutontun. Perhaps patient vo. 2 ls a good example, as approxicately 28 years have elapsed since his 6-tonth involvement with plutondus during the days of the Manhatean Project. Thss kind of infortation, even though very lialed, is human experience of the sost relevant kind for establishing value judgrents where inadequace daca erist for forzulating risk evaluations. 
RNDLATION DETECTION EQUIPIENT FOR IN VIVO MEASURENEKT OF PLUTONIUM

The three following eypes of radiation detectIng equipsent are currently used to estimate the quantity of plutonits in the body: (1) proportional counters: (2) thin sodiun lodide crystals and dual sodium ladide; and (3) cesium lodide crystals. Although these instrunents are often called "lung" counters, they cannot distinguish between radioaet ve meerlals in tite pulmonary and Iyaphatic tissue. In an effort to locallze plutonium, particularly in the hilar lymph nodes, an intraesophogeal probe 15 being developed. 11 of these instruments reasure low-encrgy $x$-rays or gatur rays fron pluconilue or contaminant radionuclides such as ${ }^{241} \mathrm{Am}$ formed by decay of ${ }^{241} \mathrm{Pu}$. The radiation enerbles of greatest interest are the 17- to 20-Kev urantun $L$-rays from ${ }^{241} \mathrm{Pu}$ and the 60-Key gama ray from 241 An. Low-energy $x$-rays also enteted by 241 Am tust be differenclated froe those given of $f$ by plut ondur.

The syotes used at the Los Alamos Scientific Laboratory to measure in vivo deposits of plutonlus In our subjects is cosprised of rwo coublned erystals, NaI backed by a So-now CSI crystel, each of wich is about 125 in diameter and 3 in thickness. Each detector functions as an anticoincidence system, resulting in a suppression of backgraund calsed by compton scatcer from higherencrgy radiations originating from within the body and in the local environment. The MDA at the 95 percent confidence level for this systew averages about $7 \mathrm{nCi}{ }^{239} \mathrm{Pu}_{\mathrm{u}}$ for a 30-minute counting period. Similar MDA values have been obtalned at other fac1lities (for example, at the Lawrence Livermore Laboratory). To achieve $\mathrm{MDA}^{\prime} \mathrm{s}$ in the range of roughiy one-third the commonly accepted $16-\mathrm{nCl}$ occupational lung burden, one wust carefully est1mate an individual's chest chickness. vitrasonic techniques are used for this purpose at LASL. Measurezents nust be made also in "low-background" counting chambers conotructed of massive iron shielding.

\section{REFERENCE}

1. K. L. Swinth, J. F. Park, and P. J. Moldofsky, "Counting Plutonium in the Tracheobronchlal Lyoph Nodes." Health Phys. 22, 899 (1972). 